\title{
Morpho-physical and Chemical Characteristics of Strongly Weathered Soils in Silago, Southern Leyte, Philippines
}

\author{
Maria Katrina B. Piamonte, Victor B. Asio and Suzette B. Lina \\ Department of Agronomy and Soil Science, College of Agriculture and Food \\ Science, Visayas State University, Baybay City, Leyte, 6521-A, Phlippines
}

\begin{abstract}
The study evaluated the morpho-physical and chemical characteristics of strongly weathered soils in Silago, Southern Leyte, one of the biodiversity hotspots in the Philippines. Examination of seven soil profiles revealed that the soils have colors ranging from yellowish brown to yellowish red, have high clay content (37.04 to $62.15 \%$ ), and moderate to high porosity values (38.49 to $52.83 \%$ ). They are deep ( $>3 \mathrm{~m}$ ) and friable when moist but very plastic and very sticky when wet. In terms of soil chemistry, most of the soils have acidic $\mathrm{pH}$ values $(<6.75)$, have low to moderate potential CEC (11.31 to $38.13 \mathrm{cmol}_{\mathrm{c}} / \mathrm{kg}$ ), low to high base saturation ( 0.76 to $69.62 \%$ ), and extremely low to medium organic matter content ( 0.07 to $2.59 \%$ ). The soils contain low to medium $\mathrm{N}(0.01$ to $0.28 \%)$, and extremely low available $\mathrm{P}(<5 \mathrm{mg} / \mathrm{kg})$. However, most of the soils contain sufficient amounts of exchangeable $\mathrm{Mg}$ ( 0.12 to $\left.9.28 \mathrm{cmol}_{c} / \mathrm{kg}\right)$, and $\mathrm{Na}\left(0.05\right.$ to $1.70 \mathrm{cmol}_{\mathrm{c}} / \mathrm{kg}$ ) except profile 5 , but are deficient in $\mathrm{Ca}\left(0.07\right.$ to $\left.0.27 \mathrm{cmol}_{\mathrm{c}} / \mathrm{kg}\right)$ and exchangeable $\mathrm{K}(0.02$ to 0.37 $\mathrm{cmol}_{\mathrm{c}} / \mathrm{kg}$ ) since the soils are acidic. Most of the soils are classified as Hapludults (USDA Soil Taxonomy) or Haplic Alisols (WRB) except the one in the toeslope which is a Hapludalf or Haplic Luvisol. The study revealed that the soils have closely related properties probably due to their similar parent material, original forest vegetation and climate. The differences in some soil properties appear to be the effect of topography.
\end{abstract}

Correspondence : V.B. Asio Address: Department of Agronomy and Soil Science, College of Agriculture and Food Science, Visayas State University, Baybay City, Leyte, 6521-A, Phlippines E-mail: vbasio@gmail.com

DOI: $10.32945 /$ atr3627.2014 


\section{INTRODUCTION}

Many soils of the humid tropics are deeply or strongly weathered and are generally nutrient-poor, acidic, and rich in sesquioxides. The high rainfall coupled with high temperature, good drainage, and geomorphologically stable land surfaces favor leaching of nutrients (Sanchez, 1976; Eswaran et al., 1992). Despite deep weathering, the effective root zone is limited by high mechanical strength, Al toxicity, $\mathrm{P}$ deficiency, and elemental imbalances in the subsoil.

In the Philippines, strongly weathered soils are common and are often degraded due to the long history of cultivation (Asio, 1996; Navarrete et al., $2009 \& 2010$ ). Many of the potential expansion sites for agriculture have strongly weathered soils, which are generally characterized by low nutrient status. Likewise, large areas of land, which have been the subject of large-scale reforestation programs in the past, have such kind of soils developed mostly from sedimentary and volcanic parent materials. The low crop yield and the failure of many of these reforestation projects in such areas can largely be attributed to improper soil management due to poor understanding of the soils.

Blum (1983) noted that the lack of a basic understanding about the ecological relationship in the ecosystem results in trial and error method of land use leading to soil degradation and ecological problems. This is partly attributed to the fact that research prioritization in the past focused more on applied research particularly on crop production and fertilization. Until now, the reports of the reconnaissance soil surveys done in the early part of the 1990s such as those by Barrera et al. (1954) and Simon et al. (1975) for the islands of Leyte and Samar, respectively, which classified Philippine soils into soil series and soil types, are still the major source of soil information.

Southern Leyte is a province located in the Eastern Visayas region of the Philippines. It occupies the southern one-fourth of the island of Leyte. The province, which has a total land area of $1,734.8 \mathrm{sq} . \mathrm{km}$, is characterized by relatively flat lands along the coastal areas, where population centers are concentrated, but is rugged and mountainous toward the interior. The town of Silago has large mountainous areas which are considered as biodiversity hotspots.

The study was conducted to evaluate the morphological, physical, and chemical characteristics of the strongly weathered soils in Silago, Southern Leyte, Philippines. 


\section{MATERIALS AND METHODS}

\section{Selection of Sampling Sites}

The study was conducted in the mountainous area of Silago, Southern Leyte, Philippines along the newly-constructed Silago-Abuyog highway (Figure 1). Seven sampling sites at various elevations and physiographic positions were selected.

\section{Field Soil Description and Sampling}

Fresh road cuts and landslide surfaces in the study sites were used for characterization. Boundaries between soil horizons were marked for proper soil morphological description following the FAO Guidelines for Soil Description (FAO, 2006).Since this is a pedological field study, the soil profile was used as the basic sampling unit. Thus, $1 \mathrm{~kg}$ soil was collected from each genetic horizon of every profile for physical and chemical analyses. Sampling was done following the quantitative method of Schlichting et al. (1995) wherein three continuous and uniform slices of soil are taken from the uppermost horizon down to the lowest. Samples were placed separately in properly-labeled plastic bags and were brought to the laboratory for air-drying and analysis. Undisturbed clods were collected for bulk density determination; the clods were placed in properly labeled plastic bags and were transported carefully to the laboratory.

\section{Laboratory Analyses}

The bulk soil samples collected (excluding the samples for bulk density determination) were pounded with a wooden mallet to pass a 2-mm sieve (fine earth sample). In addition, enough amounts of each sample were further ground to pass $0.425-\mathrm{mm}$ sieve for the analysis of soil organic matter and total nitrogen. Thereafter, the soil samples were analyzed for the following parameters:

\section{Soil Physical Properties}

Soil texture was determined by the pipette method (ISRIC, 1995),bulk density by the paraffin clod method (Blake and Hartge, 1986), and porosity was calculated from the determined bulk density 
value and a constant particle density of $2.65 \mathrm{~g} / \mathrm{cm}^{3}$. Liquid Limit and Plastic Index were estimated using the following pedotransfer equations (NSSC, 1995):

$$
\begin{aligned}
& \text { LL }(\text { Liquid limit })=0.9 \text { clay } \%+10 \\
& \text { PI (Plastic index })=\text { clay- } 21(35-55 \% \text { clay }) \\
& \text { PI (Plastic index })=\text { clay- } 15(>55 \% \text { clay })
\end{aligned}
$$

\section{Soil Chemical Properties}

Soil $\mathrm{pH}$ was analyzed potentiometrically using water and $1 \mathrm{~N} \mathrm{KCl}$ at a soil: solution ratio of 1:2.5 (ISRIC, 1995). Delta $\mathrm{pH}(\Delta \mathrm{pH})$ was determined by subtracting $\mathrm{pH}$ determined using $\mathrm{H}_{2} \mathrm{O}$ from $\mathrm{pH}$ determined using $\mathrm{KCl}\left(\mathrm{pH}_{\mathrm{KCl}}-\mathrm{pH}_{\mathrm{H} 20}\right)$ (Mekaru and Uehara, 1972).

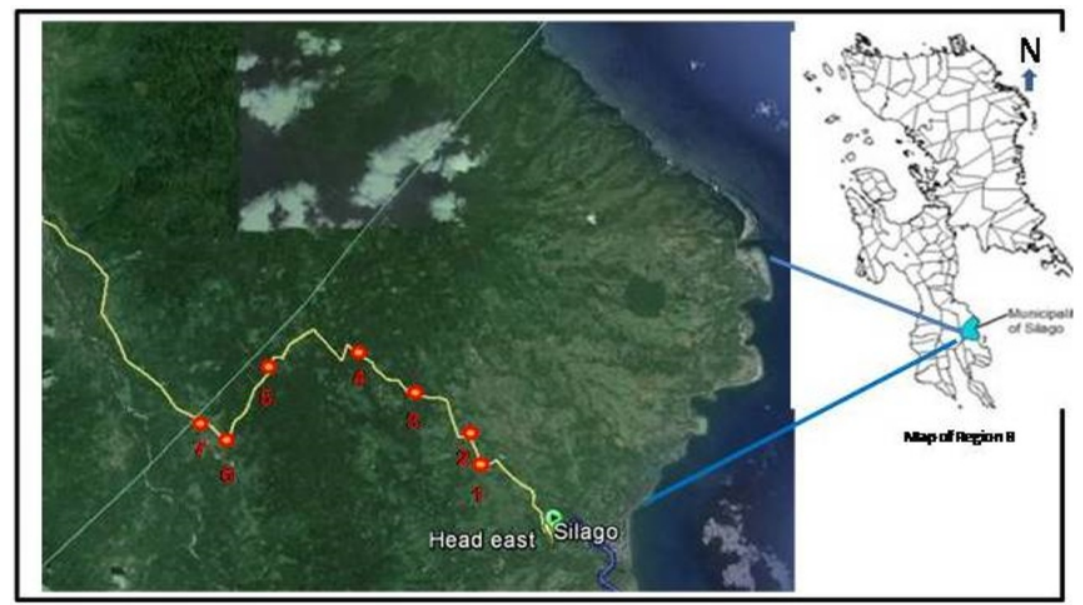

Figure 1. Map of Silago, Southern Leyte showing the sampling sites (Source: Google)

Soil organic matter (OM) was analyzed following the Modified Walkley-Black method (Nelson and Sommers, 1982), Available Phosphorus (mg/kg) by the Bray \#2 method (Bray and Kurtz, 1945), and Total Nitrogen (\%) by the micro-Kjeldahl method (ISRIC, 1995). Exchangeable Bases $(\mathrm{Ca}, \mathrm{Mg}, \mathrm{Na}$, and $\mathrm{K})\left(\mathrm{cmol}_{\mathrm{c}} / \mathrm{kg}\right)$ were extracted by $1 \mathrm{~N}$ $\mathrm{NH}_{4} \mathrm{OAc}$ (pH 7.0) according to ISRIC (1995) and quantified using an atomic absorption spectrophotometer (Varian Spectra 220 FS). Exchangeable Acidity $\left(\mathrm{Al}^{3+}\right.$ and $\left.\mathrm{H}^{+}\right)\left(\mathrm{cmol}_{c} / \mathrm{kg}\right)$ was analyzed using $1 \mathrm{~N} \mathrm{KCl}$ extraction (Thomas, 1982). Cation Exchange Capacity (potential) $\left(\mathrm{cmol}_{c} / \mathrm{kg}\right.$ ) was determined using the ammonium acetate $\left(\mathrm{NH}_{4} \mathrm{OAc}\right)$ method at $\mathrm{pH} 7.0$ 
(ISRIC, 1995). Base Saturation (\%) was calculated by dividing the sum of K, $\mathrm{Mg}$, Ca, and $\mathrm{Na}$ (bases) in $\mathrm{cmol}_{\mathrm{c}} / \mathrm{kg}$ soil by the potential $\mathrm{CEC}\left(\mathrm{CEC}_{\mathrm{pot}}\right)$ and multiplying the result by 100 . Effective Cation Exchange Capacity $\left(\mathrm{CEC}_{\text {eff }}\right)$ $\left(\mathrm{cmol}_{\mathrm{c}} / \mathrm{kg}\right.$ ) was calculated by summing up the amounts of exchangeable bases (K, Mg, Ca, and $\mathrm{Na}$ ) and total acidity $\left(\mathrm{Al}^{3+}\right.$ and $\mathrm{H}^{+}$) (ISRIC, 1995).

\section{RESULTS AND DISCUSSION}

\section{Location and Environmental Characteristics of Study Sites}

Southern Leyte is one of the six provinces of Eastern Visayas or Region VIII. It is bounded by the province of Leyte to the north, by Surigao Strait to the east, Bohol Sea to the south, and Canigao Channel, across from Bohol, to the west.It covers about one-fourth of the island of Leyte. The province is characterized by relatively flat lands along the coastal areas where population centers lie but rugged and mountainous toward the interior. The province lies within the Philippine Fault System. The major fault lines traverse the municipalities of Sogod, Libagon, St. Bernard, and San Juan to Panaon Island.

In the mountainous portion of Southern Leyte, strongly weathered soils (Ultisols) that developed from andesite, basalt, and other igneous rocks are widespread. They probably belong to the Luisiana clay that was mapped in parts of Southern Leyte, Northern Leyte, and Biliran in the 1930s (Barrera et al., 1954). Ultisols are acidic, clayey, and have generally low nutrient status. They are the most widespread soils in the Philippines.

Silago area is composed of central highland volcanic rock formation of Miocene age consisting of andesite and basalt (Figure 2) with pyroclastic materials, and Pangasugan formation consisting of conglomerates, sandstone, and shale with pyroclastic materials (JICA, 1990). The geology of an area has a profound effect on many things, from the likelihood of landslides to the availability of groundwater in wells, from the amount of shaking suffered in an earthquake to the presence of desirable minerals, from the way the landscape is shaped to the kinds of plants that grow best in the area (USGS, 2000).

Information on land use is important because it gives an idea of the nature of soil disturbances as a result of management practices as well as it influences the direction and rate of soil formation (FAO, 2006). As in most parts of Leyte, the original vegetation of the study area was tropical rainforest of the Dipterocarp forest type (Figure 3) of which an estimated 
10 percent only remains (Asio and Bande, 2005). Logging and shifting cultivations have replaced the original forest with a mosaic of agricultural land uses particularly pasture, upland crops, and patches of trees and shrubs (as discussed above). Consequently, local inhabitants do intensive cultivation and farming, triggering changes to the natural vegetation and leading to soil resource degradation. In addition, the combination of heavy rainfall, high temperature, and steep slope gradients further escalate the degradation (erosion of the topsoil, leaching leading to low soil fertility, high rate of weathering, and extensive development of residual soils problems (Hart et al., 2002). Most of the study sites in Silago show evidences of recent conversion from the original forest vegetation. This can be expected since the Abuyog-Silago highway has been completed recently.

Southern Leyte has two types of climate according to the Coronas Classification (Coronas, 1920). These are Type II and Type IV. Type II is characterized by the absence of dry season with a very pronounced maximum rain period occurring in the months of November to January. This type prevails in the eastern half of the province that includes the municipality of Sogod, Libagon, Liloan,

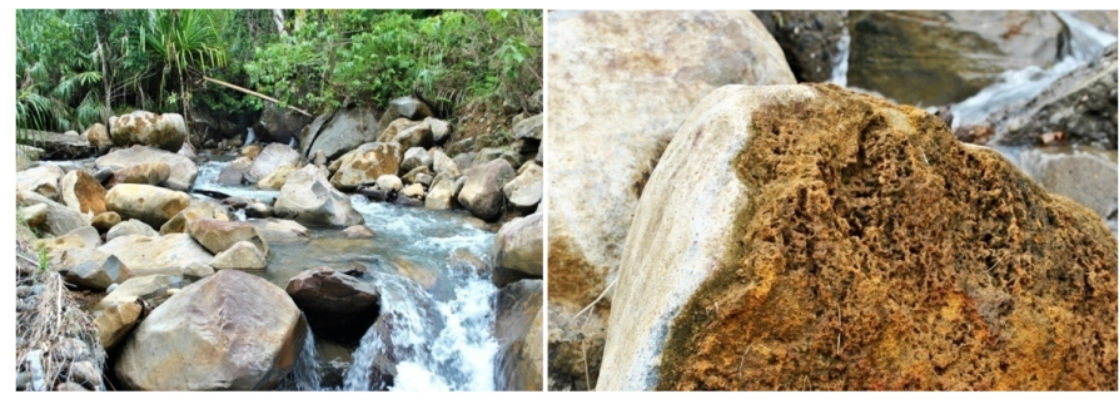

Figure 2.The basaltic-andesitic volcanic rock which is the dominant parent material of the soils in Silago, Southern Leyte (left - fresh rock; right - partly weathered rock or saprolite)

San Francisco, Pintuyan, San Ricardo, St. Bernard, San Juan, Anahawan, Hinundayan, Hinunangan, and Silago (study site). The annual mean precipitation in Southern Leyte is $1,700 \mathrm{~mm}$ and an average annual temperature of $27^{\circ} \mathrm{C}$.

Table 1 presents the environmental characteristics of the seven sampling sites.

Site 1 (Figure 4) is on the upper backslope with an elevation of $98 \mathrm{~m}$ 
above sea level (asl) in Tubod, Silago. The site is poorly drained and the soil is derived from basaltic-andesitic volcanic rocks. Vegetation includes ferns and grasses such as cogon (Imperata cylindrica).

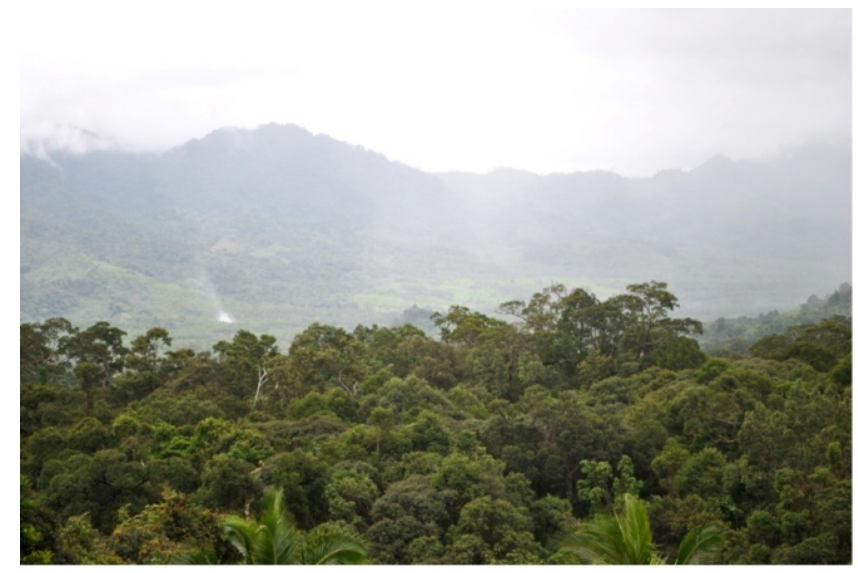

Figure 3. Photograph showing the forest vegetation of the study site in Silago, Southern Leyte

Site 2 (Figure 5) is located in Sitio Lemon, Tubod, Silago. The area is positioned in the shoulder of a volcanic mountain with an elevation of 170 masl. The area is well drained and is also dominated by ferns and cogon (Imperata cylindrica).

Site 3 (Figure 6) is an upper backslope situated in SitioLagtik of Tubod, Silago, and has an elevation of $251 \mathrm{~m}$ asl. The area is well drained, and the dominant vegetation includes ferns, cogon (Imperata cylindrica), makahiya (Mimosa pudica), agricultural crops such as coconut (Cocos nucifera), and trees such as gmelina (Gmelina arborea).

Site 4 (Figure 7) is positioned on a backslope in Tubod, Silago, with an elevation of $387 \mathrm{~m}$ asl. The site also belongs to secondary forest, and vegetation includes trees such as kakawate (Gliricidia sepium), and ipil-ipil (Leucaena leucocephala), ferns, cogon, and goatweed (Ageratum conyzoides). The area is poorly drained.

Site 5 (Figure 8) is located in Imelda, Silago. The area sampled is in a summit which is nearly level and has an elevation of $369 \mathrm{~m}$ asl. The site is well drained and considered as secondary forest, which is dominated with trees, grasses such cogon, ferns, taro (Colocasia esculenta), and goatweed.

Site 6 (Figure 9) is positioned on a footslope in Katipunan, Silago with an elevation of $194 \mathrm{~m}$ asl. The area is an abandoned agricultural farm with 
Table 1 . Site characteristics of the strongly weathered soils in Silago, Southern Leyte

\begin{tabular}{|c|c|c|c|c|c|c|c|}
\hline \multirow[t]{2}{*}{ Site Characteristics } & \multicolumn{7}{|c|}{ Site } \\
\hline & 1 & 2 & 3 & 4 & 5 & 6 & 7 \\
\hline Location & $\begin{array}{l}\text { Tubod, Silago, } \\
\text { So. Leyte }\end{array}$ & $\begin{array}{l}\text { Sitio Lemon, } \\
\text { Tubod, Silago }\end{array}$ & $\begin{array}{l}\text { SitioLagtik, Tubod, } \\
\text { Silago }\end{array}$ & Tubod 4, Silago & Imelda, Silago & Katipunan, Silago & Katipunan, Silago \\
\hline \multirow[t]{2}{*}{ Coordinates } & N10。31'54.4" & N10³2'19.5" & N10'32'59" & N103' $49^{\prime \prime}$ & N10³3'44" & N10॰33'0.7" & N10॰33'17.4" \\
\hline & E1250 09'4.1" & E1250'ㄱ․ㄹ" & E125 07'57.8" & E125 $06^{\prime} 58^{\prime \prime}$ & $\mathrm{E} 125^{\circ} 05^{\prime} 48.3^{\prime \prime}$ & $\mathrm{E} 125^{\circ} 05^{\prime} 12.2^{\prime \prime}$ & $\mathrm{E} 125^{\circ} 04^{\prime} 42.7^{\prime \prime}$ \\
\hline Elevation & $98 \mathrm{~m}$ asl & $170 \mathrm{~m}$ asl & $251 \mathrm{~m}$ asl & $387 \mathrm{~m}$ asl & $369 \mathrm{~m}$ asl & $194 \mathrm{~m}$ asl & $166 \mathrm{~m}$ asl \\
\hline Landform & $\begin{array}{l}\text { Volcanic } \\
\text { mountain }\end{array}$ & $\begin{array}{l}\text { Volcanic } \\
\text { mountain }\end{array}$ & Volcanic mountain & $\begin{array}{l}\text { Volcanic } \\
\text { mountain }\end{array}$ & $\begin{array}{l}\text { Volcanic } \\
\text { mountain }\end{array}$ & Volcanic mountain & Alluvial plain \\
\hline Slope Position & $\begin{array}{c}\text { Upper } \\
\text { backslope }\end{array}$ & Shoulder & Upper backslope & Backslope & Summit & Footslope & Toeslope \\
\hline Slope Gradient & Sloping & Gently sloping & Sloping & Sloping & Nearly level & Nearly level & Nearly level \\
\hline Exposition & North-facing & East-facing & West-facing & North-facing & North-facing & North-facing & West-facing \\
\hline Parent Material & $\begin{array}{l}\text { Basaltic- } \\
\text { andesitic } \\
\text { volcanics }\end{array}$ & $\begin{array}{l}\text { Basaltic- } \\
\text { andesitic } \\
\text { volcanics }\end{array}$ & $\begin{array}{l}\text { Basaltic-andesitic } \\
\text { volcanics }\end{array}$ & $\begin{array}{l}\text { Basaltic-andesitic } \\
\text { volcanics }\end{array}$ & $\begin{array}{l}\text { Basaltic- } \\
\text { andesitic } \\
\text { volcanics }\end{array}$ & $\begin{array}{l}\text { Basaltic-andesitic } \\
\text { volcanics }\end{array}$ & $\begin{array}{c}\text { Alluvium of } \\
\text { volcanic origin }\end{array}$ \\
\hline $\begin{array}{l}\text { Soil Moisture } \\
\text { Regime }\end{array}$ & Udic & Udic & Udic & Udic & Udic & Udic & Udic \\
\hline Soil Temperature & $\begin{array}{c}\text { Isohyperthermi } \\
\mathrm{c}\end{array}$ & Isohyperthermic & Isohyperthermic & Isohyperthermic & $\begin{array}{c}\text { Isohyperthermi } \\
\mathrm{c}\end{array}$ & Isohyperthermic & Isohyperthermic \\
\hline Erosion & No evidence & No evidence & No evidence & Slight & No evidence & No evidence & No evidence \\
\hline $\begin{array}{l}\text { Rock } \\
\text { outcrops/stoniness }\end{array}$ & Very few & Few & Few & Common & Very few & Few & Few \\
\hline Drainage & Poorly-drained & Well-drained & Well-drained & Poorly-drained & Well-drained & Poorly-drained & Well-drained \\
\hline Land-use & Agricultural & Agricultural & Agricultural & Secondary Forest & $\begin{array}{l}\text { Secondary } \\
\text { Forest }\end{array}$ & $\begin{array}{c}\text { Abandoned } \\
\text { Agricultural Farm }\end{array}$ & Secondary forest \\
\hline Vegetation & ferns, cogon & ferns, cogon & $\begin{array}{c}\text { ferns, cogon, } \\
\text { makahiya, coconut, } \\
\text { Gmelina }\end{array}$ & $\begin{array}{l}\text { kakawati, ferns, } \\
\text { cogon, goat weed }\end{array}$ & $\begin{array}{l}\text { ferns, cogon, } \\
\text { taro, goatweed }\end{array}$ & $\begin{array}{l}\text { ferns, banana, cogon, } \\
\text { coconut, jackfruit, } \\
\text { goatweed }\end{array}$ & $\begin{array}{l}\text { rice, banana, } \\
\text { palm, sambong, } \\
\text { ferns, morning } \\
\text { glory }\end{array}$ \\
\hline
\end{tabular}

Scientific names of plant species:

Imperata cylindrica

Mimosa pudica

Oryza sativa

Colocasia esculenta

makahiya

rice

taro

Gliricidia sepium
Ipomoea triloba

Leucaena leucocephala

Cocosnucifera

Blumea balsamifera

Ageratum conyzoides

Musa spp. morning glory

ipil-ipil

coconut

sambong

goatweed

Banana 
vegetation that includes banana (Musa spp.), coconut (Cocos nucifera), jackfruit (Artocarpus heterophyllus), ferns, cogon (Imperata cylindrica), and goatweed (Ageratum conyzoides). The area is poorly-drained.

Site 7 (Figure 10) is located in the toeslope of an alluvial plain in Katipunan, Silago with an elevation of $166 \mathrm{~m}$ asl. The area is well-drained and considered as a secondary forest with rice field on the side of the sampled soil profile and mixed natural vegetation which includes banana (Musa spp.), palm, sambong (Blumea balsamifera), rice (Oryza sativa), ferns, and morning glory (Ipomoea triloba).

\section{Soil Morpho-Physical Properties}

Figures 4 to 10 show the sites and soil profiles while Table 2 presents the morphological characteristics of the soils studied.

Generally the soil profiles possess Ah-Bw-Bt-C sequence of horizons. Elevation of the sampling sites appears to have no effect on the horizonation of the profiles studied. However, the physiographic positions of the soils are related to the thickness of the horizons. Presence of $B$ horizon indicates that the soil is well-developed. Thick sola were observed in almost all of the soil profiles, which may be due to deeper weathering caused by vertical water movement at the start, and deposition of eroded soil materials in the later stage of soil development. Results in solum thickness also generally agree with the literature that the thickness of solum, clay, and moisture contents increase downslope with obvious alluvial stratification at the footslope and toeslope due to constant depositional process (Butler etal., 1982).

Data show that the soil color ranges from yellowish brown to yellowish red. The yellowish red color is due to the abundance of iron oxides primarily hematite and goethite, which are important weathering products in the soil. This is especially true for soils derived from parent materials containing high amounts of iron such as the basaltic-andesitic rock in the study area. Although caution should be given in interpreting color of tropical soils (Young, 1976), it is nevertheless a useful soil property in soil genetic and classification investigations.

Soil structure is mostly subangular blocky except soil profile 2 . The consistence in most soils is very friable to very firm but generally sticky and plastic when wet. Landon (1991) stated that consistence is the property commonly used to describe the "feel" of the soil and includes soil properties such as plasticity, stickiness, and resistance to compression and 
shear, which have obvious importance for cultivation.

Fine to coarse roots can be found on the surface horizons but can no longer be observed in the lower portion particularly in the $\mathrm{BC}$ and $\mathrm{C}$ horizons of the soil profiles as roots of most crops reach only up to $\mathrm{B}$ horizon or $50 \mathrm{~cm}$ depth; although in profiles $3,4,5$, and 7, there were very fine to fine roots on the lower portion of the profile. Rock fragments are very few and common in the lower horizons since $\mathrm{BC}$ and $\mathrm{C}$ horizons are close to the bedrock and consist chiefly of weathered partially decomposed rock; although some occurrences of small rock fragments can be observed in the upper parts of the profile. Most of the horizons also show a clear smooth boundary.

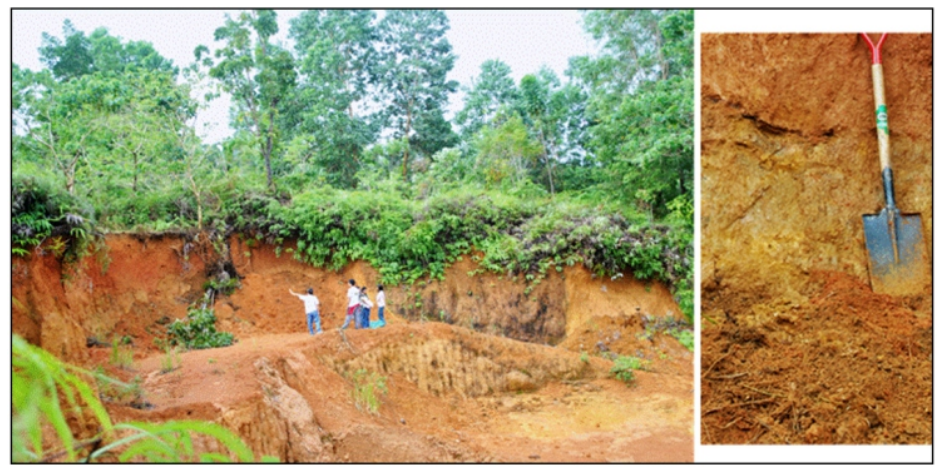

Figure 4. Photographs showing site (left) and profile characteristics (right) of soil profile 1 located at the upper backslope position at $98 \mathrm{~m}$ asl in Tubod, Silago, Southern Leyte

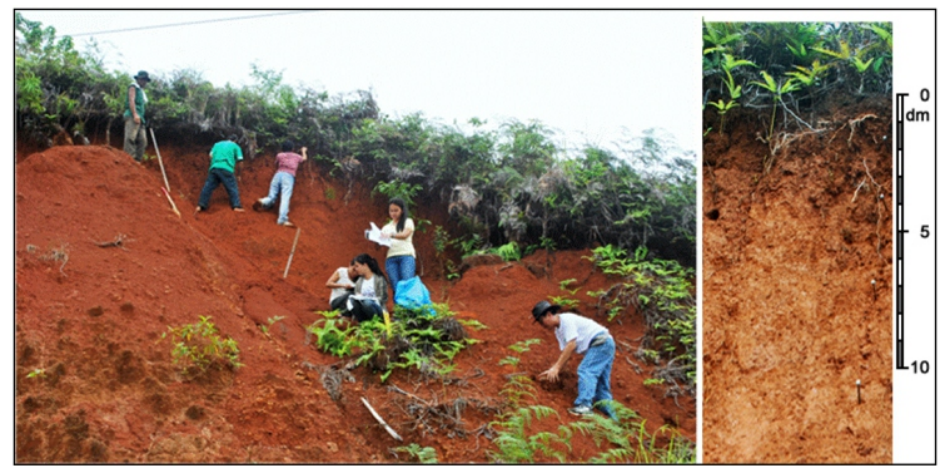

Figure 5. Photographs showing site (left) and profile characteristics (right) of soil profile 2 located at the shoulder position at $170 \mathrm{~m}$ asl in Sitio Lemon, Tubod, Silago, Southern Leyte 


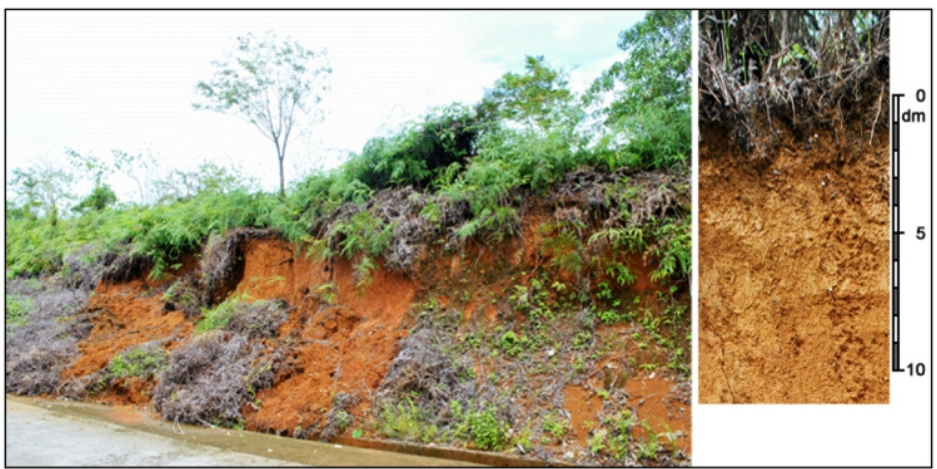

Figure 6. Photographs showing site (left) and profile characteristics (right) of soil profile 3 located at the upper backslope position at $251 \mathrm{~m}$ asl in Sitio Lagtik, Tubod, Silago, Southern Leyte

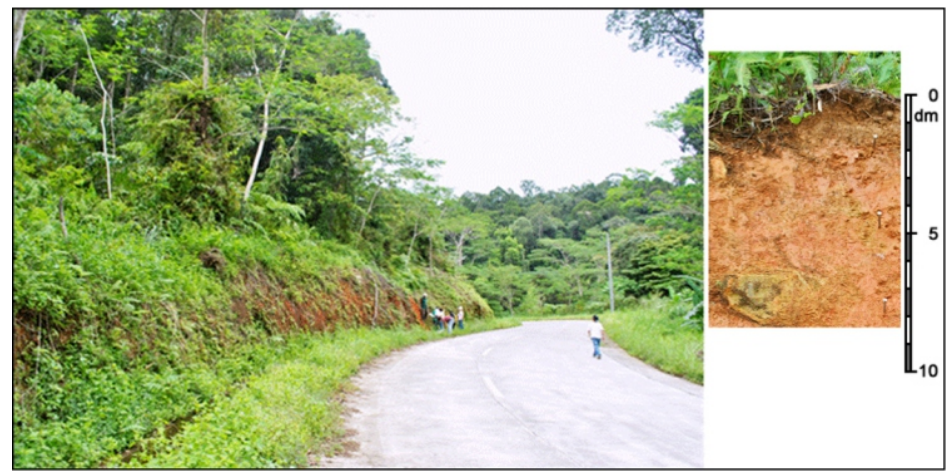

Figure 7. Photographs showing site (left) and profile characteristics (right) of soil profile 4 located at the backslope position at $387 \mathrm{~m}$ asl in Tubod 4, Silago, Southern Leyte

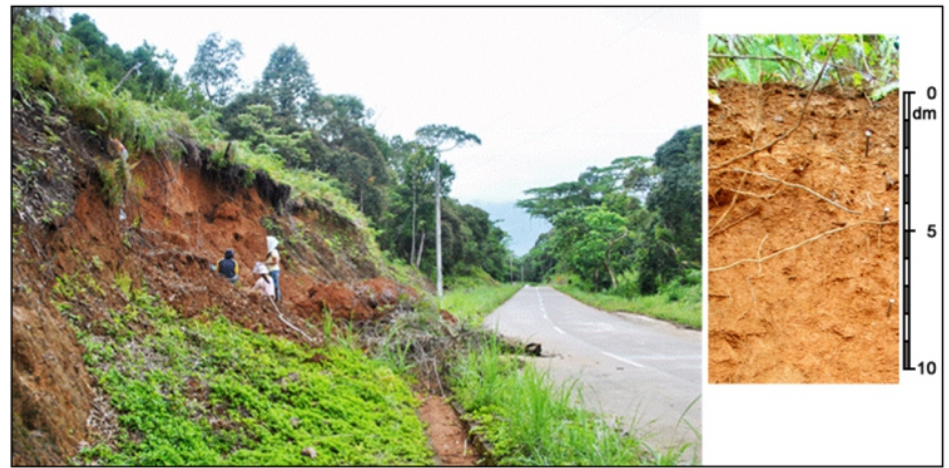

Figure 8. Photographs showing site (left) and profile characteristics (right) of soil profile 5 located at the summit position at $369 \mathrm{~m}$ asl in Imelda, Silago, Southern Leyte 


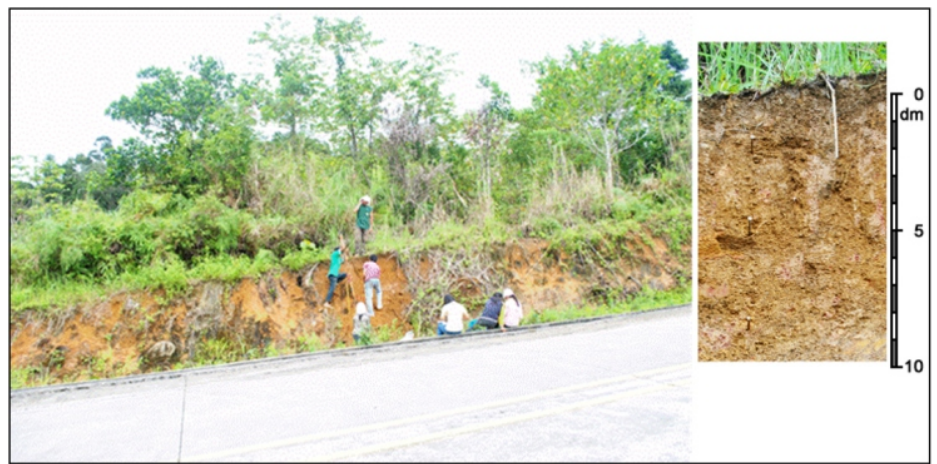

Figure 9. Photographs showing site (left) and profile characteristics (right) of soil profile 6 located at the footslope position at $194 \mathrm{~m}$ asl in Katipunan, Silago, Southern Leyte

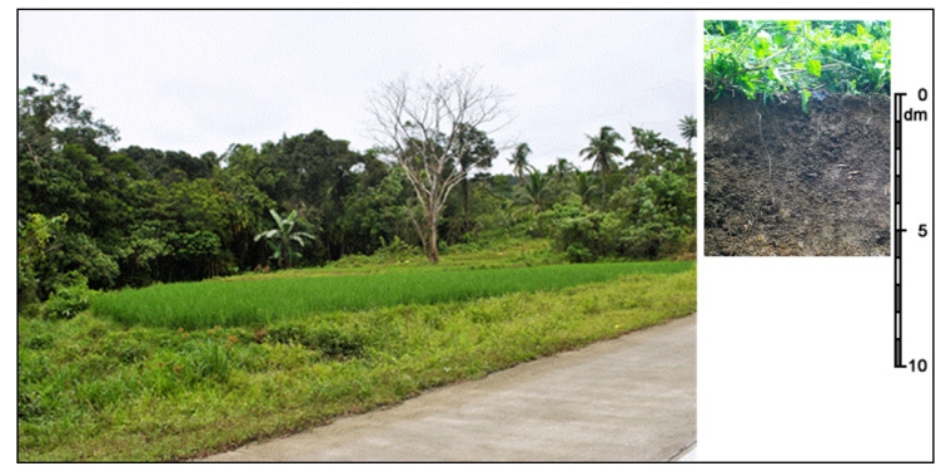

Figure 10. Photographs showing site (left) and profile characteristics (right) of soil profile 7 located at the toeslope position at $166 \mathrm{~m}$ asl in Katipunan, Silago, Southern Leyte 
Table 2. Morphological characteristics of the strongly weathered soils in Silago, Southern Leyte

\begin{tabular}{|c|c|c|c|c|c|c|c|c|c|c|}
\hline \multirow{2}{*}{$\begin{array}{c}\text { Soil Profile/ } \\
\text { Horizon }\end{array}$} & \multirow[t]{2}{*}{ Depth (cm) } & \multirow{2}{*}{$\begin{array}{c}\text { Soil Color } \\
\text { (Munsell Color-dry) }\end{array}$} & \multirow[t]{2}{*}{ Texture } & \multirow[t]{2}{*}{ Structure } & \multicolumn{2}{|c|}{ Consistence } & \multirow[t]{2}{*}{ Roots } & \multirow[t]{2}{*}{ Pores } & \multirow[t]{2}{*}{ Boundary } & \multirow{2}{*}{$\begin{array}{c}\text { Rock } \\
\text { Fragments }\end{array}$} \\
\hline & & & & & Moist & Wet & & & & \\
\hline \multicolumn{11}{|c|}{ Profile 1 (Tubod) } \\
\hline $\mathrm{Ah}$ & $0-18$ & $\begin{array}{c}\text { 10YR 3/4 (dark yellowish } \\
\text { brown) }\end{array}$ & CL & $1 \mathrm{fsbk}$ & $\mathrm{fr}$ & st\&pl & $\mathrm{mm}$ & cvf & as & $\mathrm{n}$ \\
\hline Bw & $18-46$ & 10YR 5/8 (yellowish brown) & $\mathrm{C}$ & $1 \mathrm{fsbk}$ & fi & st\&pl & $\mathrm{cf}$ & fvf & as & $\mathrm{n}$ \\
\hline Bt1 & $46-72$ & 5YR 5/8 (yellowish red) & $\mathrm{C}$ & $2 \mathrm{fsbk}$ & vfi & vst\&vpl & $\mathrm{fc}$ & fvf & gs & $\mathrm{n}$ \\
\hline $\mathrm{Bt} 2$ & $72-104$ & 5YR 5/8 (yellowish red) & $\mathrm{C}$ & $2 \mathrm{fsbk}$ & vfi & vst\&vpl & vfvf & fvf & gs & $\mathrm{n}$ \\
\hline $\mathrm{Bt} 3$ & $104-135$ & 5YR 5/8 (yellowish red) & $\mathrm{C}$ & $2 \mathrm{fsbk}$ & vfi & vst\&vpl & $\mathrm{n}$ & fvf & gs & $\mathrm{n}$ \\
\hline $\mathrm{Bt} 4$ & $135-172$ & 5YR 5/8 (yellowish red) & $\mathrm{C}$ & $2 \mathrm{fsbk}$ & vfi & vst\&vpl & $\mathrm{n}$ & fvf & gs & $\mathrm{n}$ \\
\hline $\mathrm{BC}$ & $172-206$ & 5YR 5/8 (yellowish red) & $\mathrm{C}$ & $2 \mathrm{fsbk}$ & vfi & vst\&vpl & $\mathrm{n}$ & fvf & gs & $\mathrm{c}$ \\
\hline \multicolumn{11}{|c|}{ Profile 2 (Sitio Lemon) } \\
\hline $\mathrm{Ah}$ & $0-21$ & 5YR 4/4 (reddish brown) & $\mathrm{SiCL}$ & $1 \mathrm{mg}$ & $\mathrm{fr}$ & vst\&pl & $\mathrm{mf}$ & $\mathrm{mf}$ & cs & $\mathrm{c}$ \\
\hline $\mathrm{Bw}$ & $21-44$ & 5YR 4/6 (yellowish red) & $\mathrm{C}$ & $1 \mathrm{mg}$ & $\mathrm{fr}$ & vst\&pl & $\mathrm{cf}$ & $\mathrm{cf}$ & $\mathrm{cs}$ & $\mathrm{v}$ \\
\hline Bt1 & $44-75$ & 5YR 4/6 (yellowish red) & $\mathrm{C}$ & $1 \mathrm{fsbk}$ & $\mathrm{fr}$ & vst\&pl & vff & vfvf & cs & $\mathrm{v}$ \\
\hline $\mathrm{Bt} 2$ & $75-113$ & 5YR 5/8 (yellowish red) & $\mathrm{C}$ & $1 \mathrm{fsbk}$ & $\mathrm{fr}$ & vst\&pl & vfvf & vfvf & cs & $\mathrm{v}$ \\
\hline $\mathrm{Bt} 3$ & $113-276$ & 5YR 5/8 (yellowish red) & $\mathrm{C}$ & $1 \mathrm{fsbk}$ & $\mathrm{fr}$ & vst\&pl & $\mathrm{n}$ & vfvf & cs & $\mathrm{v}$ \\
\hline $\mathrm{C}$ & 276 below & 5YR 5/8 (yellowish red) & $\mathrm{C}$ & $1 \mathrm{fsbk}$ & fr & vst\&pl & $\mathrm{n}$ & vfvf & cs & $\mathrm{a}$ \\
\hline \multicolumn{11}{|c|}{ Profile 3 (SitioLagtik) } \\
\hline $\mathrm{Ah}$ & $0-20$ & 10YR 4/3 (dark brown) & $\mathrm{CL}$ & $1 \mathrm{fsbk}$ & fr & st\&spl & $\mathrm{mf}$ & $\mathrm{cf}$ & cs & $\mathrm{v}$ \\
\hline $\mathrm{Bw}$ & $20-39$ & 10YR 5/6 (yellowish brown) & CL & $1 \mathrm{fsbk}$ & fr & st\&spl & $\mathrm{cf}$ & $\mathrm{cf}$ & cs & $\mathrm{v}$ \\
\hline Bt1 & $39-73$ & 10YR 5/8 (yellowish brown) & $\mathrm{C}$ & $2 \mathrm{msbk}$ & fr & st\&spl & vff & vfvf & gs & $\mathrm{n}$ \\
\hline Bt2 & $73-98$ & 10YR 5/8 (yellowish brown) & $\mathrm{C}$ & $2 \mathrm{msbk}$ & $\mathrm{fr}$ & st\&spl & vfvf & vfvf & gw & $\mathrm{n}$ \\
\hline Bt3 & $98-142$ & 10YR 5/8 (yellowish brown) & $\mathrm{C}$ & $2 \mathrm{msbk}$ & $\mathrm{fr}$ & vst\&vpl & vfvf & vfvf & †๐̆ & - \\
\hline.$\dot{\mathrm{C}}_{\mathrm{G}}$ & $142-180$ & 5YR 5/8 (yellowish red) & $\mathrm{C}$ & $2 \mathrm{msbk}$ & fr & vst\&vpl & vfvf & vfvf & gw & $\mathrm{n}$ \\
\hline $\mathrm{BC}$ & 180 below & 5YR 5/8 (yellowish red) & $\mathrm{C}$ & $2 \mathrm{msbk}$ & $\mathrm{fr}$ & vst\&vpl & vfvf & vfvf & cs & $\mathrm{c}$ \\
\hline \multicolumn{11}{|c|}{ Profile 4 (Tubod 4) } \\
\hline Ah & $0-18$ & 10YR 5/6 (yellowish brown) & $\mathrm{SiC}$ & $1 \mathrm{fsbk}$ & $\mathrm{fr}$ & st\&pl & $\mathrm{mf}$ & $\mathrm{mf}$ & cs & c \\
\hline Bt1 & $18-45$ & 5YR 5/8 (yellowish red) & $\mathrm{C}$ & $2 \mathrm{msbk}$ & vfi & vst\&vpl & $\mathrm{cf}$ & $\mathrm{cvf}$ & gs & $\mathrm{v}$ \\
\hline $\mathrm{Bt} 2$ & $45-77$ & 5YR 5/8 (yellowish red) & $\mathrm{C}$ & $2 \mathrm{msbk}$ & vfi & vst\&vpl & ff & $\mathrm{cvf}$ & gw & $\mathrm{v}$ \\
\hline $\mathrm{Bt} 3$ & $77-106$ & 5YR 5/8 (yellowish red) & $\mathrm{C}$ & $2 \mathrm{msbk}$ & vfi & vst\&vpl & ff & $\mathrm{cvf}$ & gw & $\mathrm{v}$ \\
\hline Bt4 & $106-145$ & 5YR 5/8 (yellowish red) & $\mathrm{C}$ & $2 \mathrm{msbk}$ & vfi & vst\&vpl & ff & cvf & gw & $\mathrm{v}$ \\
\hline $\mathrm{C}$ & 145 below & 5YR 5/8 (yellowish red) & $\mathrm{C}$ & $1 \mathrm{fsbk}$ & vfi & vst\&vpl & $\mathrm{ff}$ & vfvf & cs & $\mathrm{c}$ \\
\hline
\end{tabular}


Table 2 Continuation

\begin{tabular}{|c|c|c|c|c|c|c|c|c|c|c|}
\hline \multirow{2}{*}{$\begin{array}{c}\text { Soil Profile } \\
\text { Horizon }\end{array}$} & \multirow[t]{2}{*}{ Depth (cm) } & \multirow{2}{*}{$\begin{array}{c}\text { Soil Color } \\
\text { (Munsell Color-dry) }\end{array}$} & \multirow[t]{2}{*}{ Texture } & \multirow[t]{2}{*}{ Structure } & \multicolumn{2}{|c|}{ Consistence } & \multirow[t]{2}{*}{ Roots } & \multirow[t]{2}{*}{ Pores } & \multirow[t]{2}{*}{ Boundary } & \multirow{2}{*}{$\begin{array}{c}\text { Rock } \\
\text { Fragments }\end{array}$} \\
\hline & & & & & Moist & Wet & & & & \\
\hline \multicolumn{11}{|c|}{ Profile 5 (Imelda) } \\
\hline $\mathrm{Ah}$ & $0-26$ & 5YR 4/6 (yellowish red) & $\mathrm{CL}$ & $1 \mathrm{fsbk}$ & fr & sst\&spl & $\mathrm{mc}$ & $\mathrm{cf}$ & cs & $\mathrm{n}$ \\
\hline $\mathrm{Bw}$ & $26-51$ & 5YR 4/6 (yellowish red) & CL & $1 \mathrm{fsbk}$ & $\mathrm{fr}$ & sst\&spl & $\mathrm{mc}$ & $\mathrm{cf}$ & gs & $\mathrm{n}$ \\
\hline Bt1 & $51-80$ & 5YR 4/6 (yellowish red) & $\mathrm{C}$ & $2 \mathrm{msbk}$ & fi & st\&pl & $\mathrm{cc}$ & $\mathrm{cvf}$ & $\mathrm{gw}$ & $\mathrm{n}$ \\
\hline Bt2 & $80-95$ & 5YR 5/6 (yellowish red) & $\mathrm{C}$ & $1 \mathrm{fsbk}$ & fr & vst\&vpl & $\mathrm{fc}$ & vfvf & gw & $\mathrm{n}$ \\
\hline $\mathrm{Bt} 3$ & $95-135$ & 5YR 4/6 (yellowish red) & $\mathrm{C}$ & $1 \mathrm{fsbk}$ & fr & vst\&vpl & $\mathrm{fc}$ & vfvf & gw & $\mathrm{n}$ \\
\hline $\mathrm{BC}$ & 135 below & 5YR 4/6 (yellowish red) & $\mathrm{C}$ & 1 fsbk & fr & vst\&vpl & $\mathrm{ff}$ & vfvf & cs & $\mathrm{c}$ \\
\hline \multicolumn{11}{|c|}{ Profile 6 (Katipunan 1) } \\
\hline Ap & $0-23$ & 7.5YR 3/4 (dark brown) & CL & $1 \mathrm{fg}$ & vfr & st\&pl & $\mathrm{ff}$ & $\mathrm{cf}$ & cs & $\mathrm{v}$ \\
\hline Bt1 & $23-52$ & 2.5Y 5/6 (light olive brown) & $\mathrm{CL}$ & $1 \mathrm{fsbk}$ & $\mathrm{fr}$ & st\&pl & vff & fvf & gs & $\mathrm{n}$ \\
\hline Bt2 & $52-86$ & 7.5YR 6/8 (reddish yellow) & $\mathrm{C}$ & $2 \mathrm{msbk}$ & fi & vst\&vpl & vfvf & vfvf & gs & $\mathrm{n}$ \\
\hline $\mathrm{BC} 1$ & $86-127$ & 7.5YR 6/8 (reddish yellow) & $\mathrm{C}$ & $2 \mathrm{msbk}$ & fi & vst\&vpl & $\mathrm{n}$ & vfvf & as & $\mathrm{n}$ \\
\hline $\mathrm{BC} 2$ & 127 below & 2.5 Y 5/6 (light olive brown) & $\mathrm{C}$ & $2 \mathrm{msbk}$ & fi & vst\&vpl & $\mathrm{n}$ & vfvf & aw & $\mathrm{n}$ \\
\hline \multicolumn{11}{|c|}{ Profile 7 (Katipunan 2) } \\
\hline Ah1 & $0-25$ & 7.5YR 3/4 (dark brown) & $\mathrm{SiC}$ & 1 fsbk & fr & sst\&spl & $\mathrm{mf}$ & $\mathrm{mf}$ & cs & $\mathrm{v}$ \\
\hline Ah2 & $25-46$ & 7.5YR 3/4 (dark brown) & $\mathrm{SiC}$ & $1 \mathrm{fsbk}$ & fr & sst\&spl & $\mathrm{mf}$ & $\mathrm{mf}$ & $\mathrm{cs}$ & $\mathrm{v}$ \\
\hline $\mathrm{Bw}$ & $46-72$ & 7.5YR 3/4 (dark brown) & $\mathrm{C}$ & $1 \mathrm{fsbk}$ & fr & vst\&pl & $\mathrm{mf}$ & $\mathrm{cf}$ & cs & $\mathrm{v}$ \\
\hline Bt1 & $72-113$ & $\begin{array}{c}\text { 10YR 4/4 (dark yellowish } \\
\text { brown) }\end{array}$ & $\mathrm{C}$ & $1 \mathrm{fsbk}$ & fr & vst\&pl & $\mathrm{cc}$ & $\mathrm{cf}$ & cs & $\mathrm{v}$ \\
\hline $\mathrm{Bt} 2$ & $113-143$ & 10YR 5/8 (yellowish brown) & $\mathrm{C}$ & $2 \mathrm{fsbk}$ & fr & vst\&pl & $\mathrm{cc}$ & $\mathrm{cf}$ & cs & $\mathrm{v}$ \\
\hline $\mathrm{Bt} 3$ & 143 below & $\begin{array}{c}10 \text { YR } 4 / 4 \text { (dark yellowish } \\
\text { brown) }\end{array}$ & $\mathrm{C}$ & $2 \mathrm{fsbk}$ & fr & vst\&pl & $\mathrm{cc}$ & $\mathrm{cf}$ & cs & $\mathrm{v}$ \\
\hline
\end{tabular}


Symbols

(Key to Abbreviations in Table 2)

a. Soil texture

SiC- Silty clay

C- Clay

SiCL-Silty Clay Loam

b. Soil structure

Grade

1-weak

2-moderate

3-strong

c. Soil consistency-moist

fr- friable; vfr- very friable;

fi- firm; vfi- very firm

Soil consistency-wet

st- sticky; sst- slightly sticky;

vst- very sticky;

pl- plastic; spl- slightly plastic;

vpl- very plastic

d. Roots
Abundance
n-none; f-few; vf- very few;
c-common; m-many
Size: vf-very fine; $\mathrm{f}$ - fine; - medium;
c- coarse

e. Soil pores

Abundance

vf- very few; f-few; c-common; mmany

Size: vf-very fine; f-fine; m-medium;

Type

c-coarse

g-granular

-subangular blocky

f. Horizon boundary

Distinctness: a-abrupt; c-clear; ggradual

Topography: s- smooth; w- wavy

g. Rock Fragments

n-none; $v$-very few; c-common

Particle size distribution expresses the relative sizes of particles comprising a given soil in terms of percentage by weight of the individual sizes. Most of the soils in each site are clayey with clay content ranging from 37.04 to 62.15 percent (Figure 11). Results also show that all soil profiles have increasing clay content with depth, indicating the presence of an argic (or argillic) horizon (Figure 12). The high clay content of the soils is probably from formation of clay during the weathering of the basalticandesitic parent material. This suggests the important role of parent material in the development of strongly weathered soils such as the soils studied. Also, through time soils undergo several processes and developments which would result to clay accumulation. Bulk density (Db), 
expressed in $\mathrm{g} / \mathrm{cm}^{3}$, is used as an index of compaction and porosity and directly affects root development and gas movement in the soil. Figure 13 shows that bulk density values are lower in upper horizons but tend to increase in subsurface horizons, ranging from 1.25 to $1.63 \mathrm{~g} / \mathrm{cm}^{3}$ (Table 3).

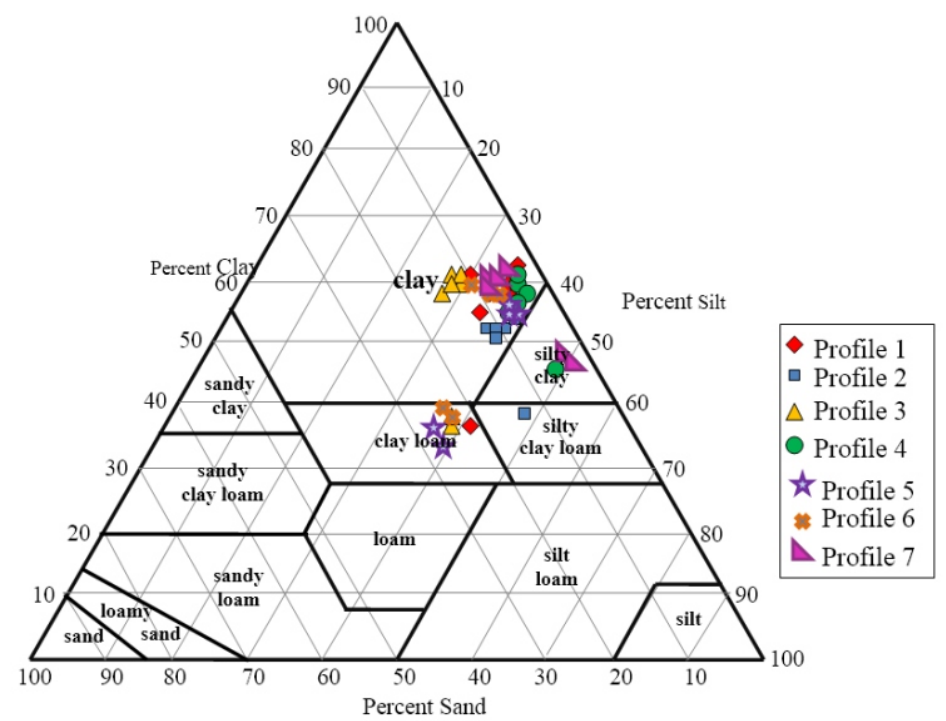

Figure 11.Textural classes of strongly weathered soils in Silago, Southern Leyte based on the USDA textural triangle

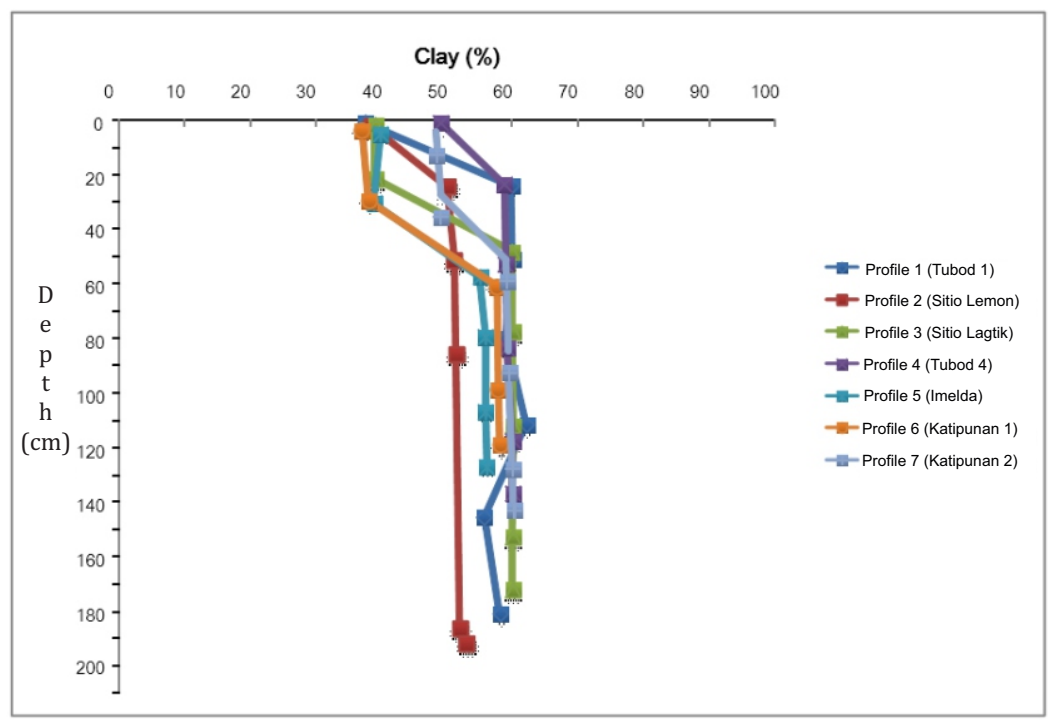

Figure 12. Depth function of clay content of the strongly weathered soils in Silago, Southern Leyte 


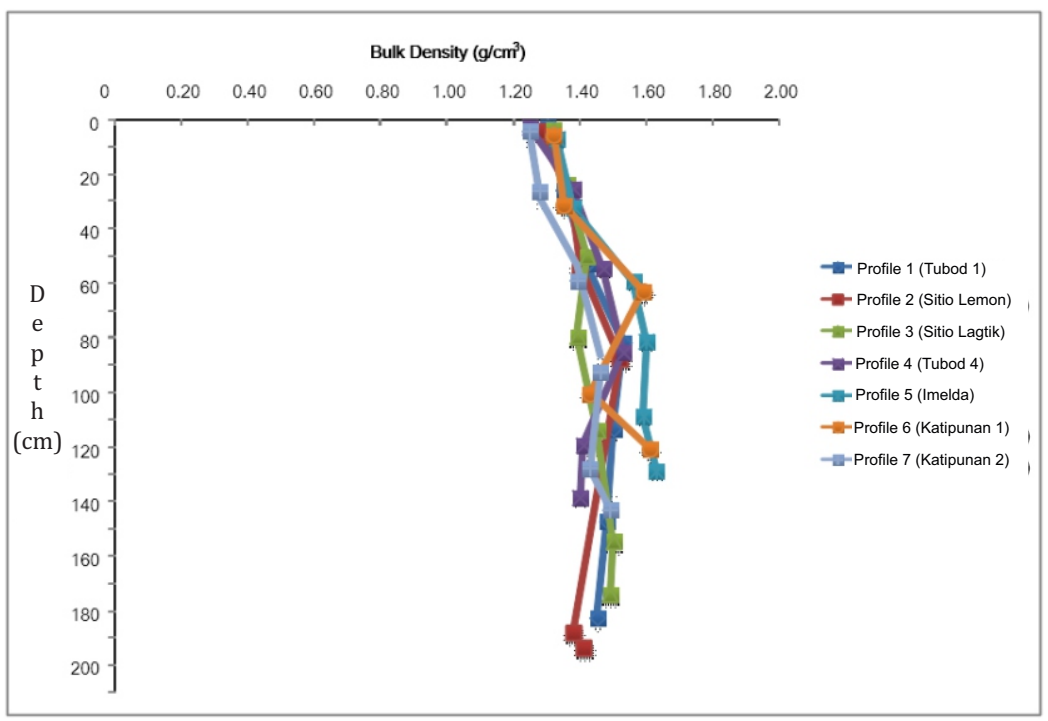

Figure 13. Depth function of bulk density of the strongly weathered soils in Silago, Southern Leyte

The lower bulk density values can be attributed to the higher porosity values on the surface horizon brought about by good soil aggregation. The increasing bulk density values with depth can be attributed to the higher clay content of the subsoil and to the lower biological activity. Lower bulk density values suggest better aeration on the surface horizon compared to the subsurface horizon.

Liquid limit is the percent water content of a soil at the arbitrarily defined boundary between the liquid and plastic states; while plastic index is the range of water content over which a soil behaves plastically. Results show that all soils have high liquid limit ranging from 43.34 to 65.94 and plastic index with values ranging from 16.60 to 47.15 (Table 3). The data suggest that the soils exhibit liquid states at water content above $50 \%$. This means that the soils are prone to liquid movement at this indicated water content, which can happen during heavy storms or typhoons.

\section{Soil Chemical Properties}

Soil reaction $(\mathrm{pH})$ expresses the activity of the hydrogen ions in the soil solution. It affects the availability of mineral nutrients to plants as well as many soil formation processes (Jahn et al., 2002). Figure 14 and Table 4 show that all soils have low $\mathrm{pH}-\mathrm{H}_{2} \mathrm{O}$ values ranging from 4.52 to 6.75 . The 
Table 3. Physical characteristics of the strongly weathered soils in Silago, Southern Leyte

\begin{tabular}{|c|c|c|c|c|c|c|c|c|c|}
\hline $\begin{array}{l}\text { Soil Profile/ } \\
\text { Horizon }\end{array}$ & Depth (cm) & Sand & $\begin{array}{l}\text { PSA (\%) } \\
\text { Silt }\end{array}$ & Clay & $\begin{array}{l}\text { Textural } \\
\text { Class }\end{array}$ & $\begin{array}{l}\text { Bulk Density } \\
\left(\mathrm{g} / \mathrm{cm}^{3}\right)\end{array}$ & $\begin{array}{c}\text { Porosity } \\
(\%)\end{array}$ & $\begin{array}{l}\text { Liquid } \\
\text { Limit* }\end{array}$ & $\begin{array}{l}\text { Plastic } \\
\text { Index** }\end{array}$ \\
\hline \multicolumn{10}{|c|}{ Profile 1 (Tubod) } \\
\hline $\mathrm{Ah}$ & $0-18$ & 21.31 & 41.09 & 37.60 & Clay loam & 1.30 & 50.94 & 43.84 & 16.60 \\
\hline Bt1 & $46-72$ & 9.78 & 30.20 & 60.02 & Clay & 1.42 & 46.42 & 64.02 & 45.02 \\
\hline $\mathrm{Bt} 2$ & $72-104$ & 6.05 & 35.00 & 58.95 & Clay & 1.53 & 42.26 & 63.06 & 43.95 \\
\hline Bt3 & $104-135$ & 4.65 & 33.20 & 62.15 & Clay & 1.50 & 43.40 & 65.94 & 47.15 \\
\hline \multicolumn{10}{|c|}{ Profile 2 (Sitio Lemon) } \\
\hline $\mathrm{Ah}$ & $0-21$ & 12.5 & 49 & 38.50 & $\begin{array}{l}\text { Silty clay } \\
\text { loam }\end{array}$ & 1.27 & 52.08 & 44.65 & 17.50 \\
\hline $\mathrm{Bw}$ & $21-44$ & 11.07 & 38.88 & 50.05 & Clay & 1.37 & 48.30 & 55.05 & 29.05 \\
\hline Bt1 & $44-75$ & 10.90 & 37.98 & 51.12 & Clay & 1.40 & 47.17 & 56.01 & 30.12 \\
\hline $\mathrm{Bt} 2$ & $75-113$ & 10.54 & 38.01 & 51.45 & Clay & 1.52 & 42.64 & 56.31 & 30.45 \\
\hline Bt1 & $39-73$ & 11.26 & 28.85 & 59.89 & Clay & 1.42 & 46.42 & 63.90 & 44.89 \\
\hline $\mathrm{Bt} 2$ & $73-98$ & 11.33 & 28.65 & 60.02 & Clay & 1.39 & 47.55 & 64.02 & 45.02 \\
\hline $\mathrm{Bt} 3$ & $98-142$ & 10.88 & 29.00 & 60.12 & Clay & 1.45 & 45.28 & 64.11 & 45.12 \\
\hline $\mathrm{Bt} 4$ & $142-180$ & 11.08 & 28.95 & 59.97 & Clay & 1.50 & 43.40 & 63.97 & 44.97 \\
\hline $\mathrm{BC}$ & 180 below & 11.96 & 27.99 & 60.05 & Clay & 1.49 & 43.77 & 64.05 & 45.05 \\
\hline \multicolumn{10}{|c|}{ Profile 4 (Tubod 4) } \\
\hline $\mathrm{Ah}$ & $0-18$ & 5.50 & 45.50 & 49.00 & Silty clay & 1.25 & 52.83 & 54.10 & 28.00 \\
\hline Bt1 & $18-45$ & 6.13 & 35.12 & 58.75 & Clay & 1.38 & 47.92 & 62.88 & 43.75 \\
\hline $\mathrm{Bt} 2$ & $45-77$ & 5.50 & 35.50 & 59.00 & Clay & 1.47 & 44.53 & 63.10 & 44.00 \\
\hline $\mathrm{Bt} 3$ & $77-106$ & 4.87 & 36.00 & 59.13 & Clay & 1.53 & 42.26 & 63.22 & 44.13 \\
\hline $\mathrm{Bt} 4$ & $106-145$ & 4.01 & 35.99 & 60.00 & Clay & 1.41 & 46.79 & 64.00 & 45.00 \\
\hline $\mathrm{C}$ & 145 below & 5.14 & 34.87 & 59.99 & Clay & 1.40 & 47.17 & 63.99 & 44.99 \\
\hline
\end{tabular}


Table 3 Continuation

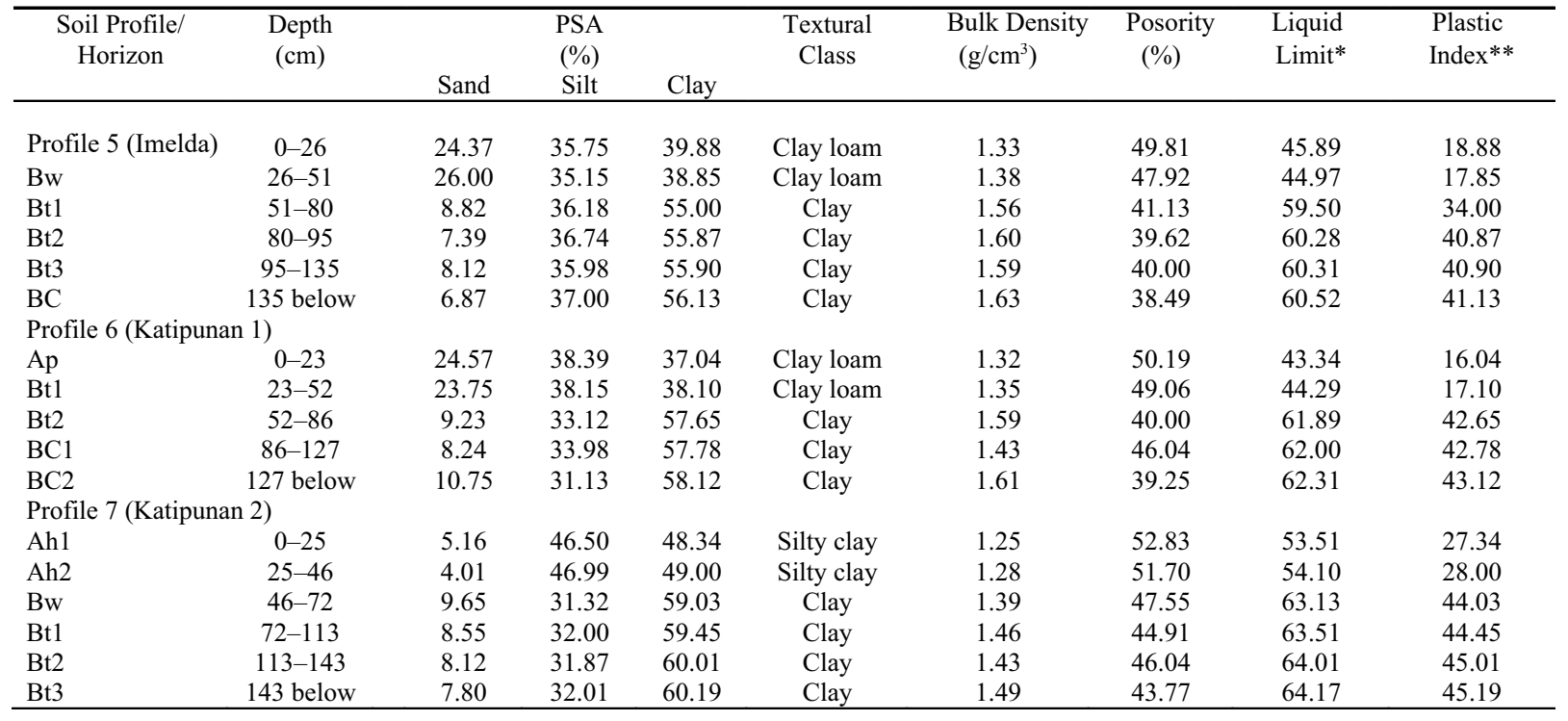


$\mathrm{pH}-\mathrm{H}_{2} \mathrm{O}$ values tend to slightly decrease with depth. The low $\mathrm{pH}-\mathrm{H}_{2} \mathrm{O}$ values can be attributed to the parent material, and the soils are weathered so they are expected to be acidic. On the other hand, $\mathrm{pH}$ values in $\mathrm{KCl}$ ranging from 3.74 to 6.04 are lower than $\mathrm{pH}$ values in $\mathrm{H}_{2} \mathrm{O}$ as expected and tend to slightly decrease with depth. The use of $1 \mathrm{M} \mathrm{KCl}$ is based on the premise that $\mathrm{K}$-ions can replace weakly adsorbed $\mathrm{H}$ - and $\mathrm{Al}$-ions, which is not possible with $\mathrm{H}_{2} \mathrm{O}$ (Schlichting et al., 1995). The $\mathrm{pH}-\mathrm{KCl}$ is more stable than the $\mathrm{pH}-\mathrm{H}_{2} \mathrm{O}$ because it limits suspension and stirring effects (Bache, 1988 as cited by Asio et al., 1992). Results also show that all soils have negative $\Delta \mathrm{pH}$ (Table 4) indicating that the soil colloids have net negative charge and they possess cation exchange capacity.

Soil OM includes all the organic materials derived from plants and animals incorporated into the soil or lying on its surface, which is either living or in various stages of decomposition. Results revealed that $\mathrm{OM}$ and total $\mathrm{N}$ are high in the upper horizons and then decrease considerably with depth (Figures 15 and Table 4). The decrease in OM with depth can be attributed to the accumulation of leaf litter as well as to the higher amount of roots of grasses concentrated in the surface horizon (Navarrete et al., 2000 ). Profile 7 has the highest $\mathrm{OM}$ and total $\mathrm{N}$ content that is probably due to the prolonged fallow and the site is in a toeslope position suggesting the influence of deposition processes.

Phosphorus is a critical element in natural and agricultural ecosystems (Brady and Weil, 1999). Tropical soils are generally P deficient; and in many cases, $\mathrm{P}$ is the limiting nutrient in agriculture (Sanchez and Logan, 1992).

Available P refers to the $\mathrm{P}$ that is readily available to plant. Available $\mathrm{P}$ contents are low in all soils in the seven profiles and slightly decrease with soil depth (Table 4). This may be due to the acidic condition of the soils, which causes precipitation of the element. Phosphorus occurs in the soil solution as the negatively-charged phosphate ion $\mathrm{H}_{2} \mathrm{PO}_{4}^{-}$in acid soils. These ions react readily with iron, aluminium, and manganese compounds in acid soils. They become strongly attached to the surfaces of these compounds or form insoluble phosphate precipitates. These reactions remove immediately available phosphate ions from the soil solution. The upper layer of the soil usually retains almost all of the phosphorus so this means that very little phosphorus moves into or through the subsoil (Brady and Weil, 1999). 


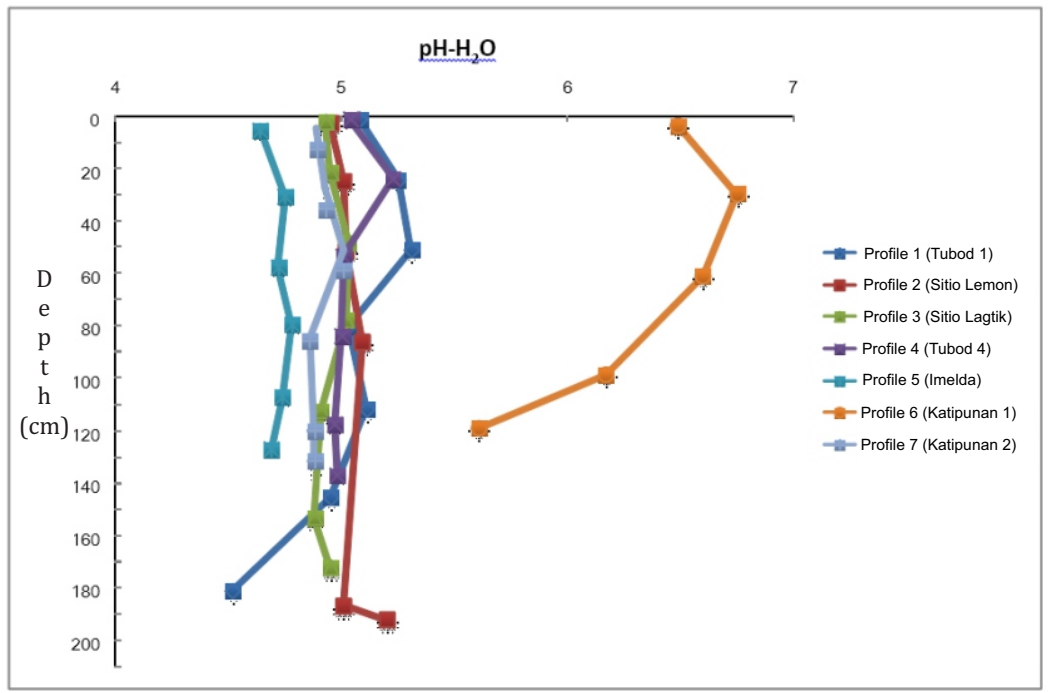

Figure 14. Depth function of $\mathrm{pH}-\mathrm{H}_{2} \mathrm{O}$ of the strongly weathered soils in Silago, Southern Leyte

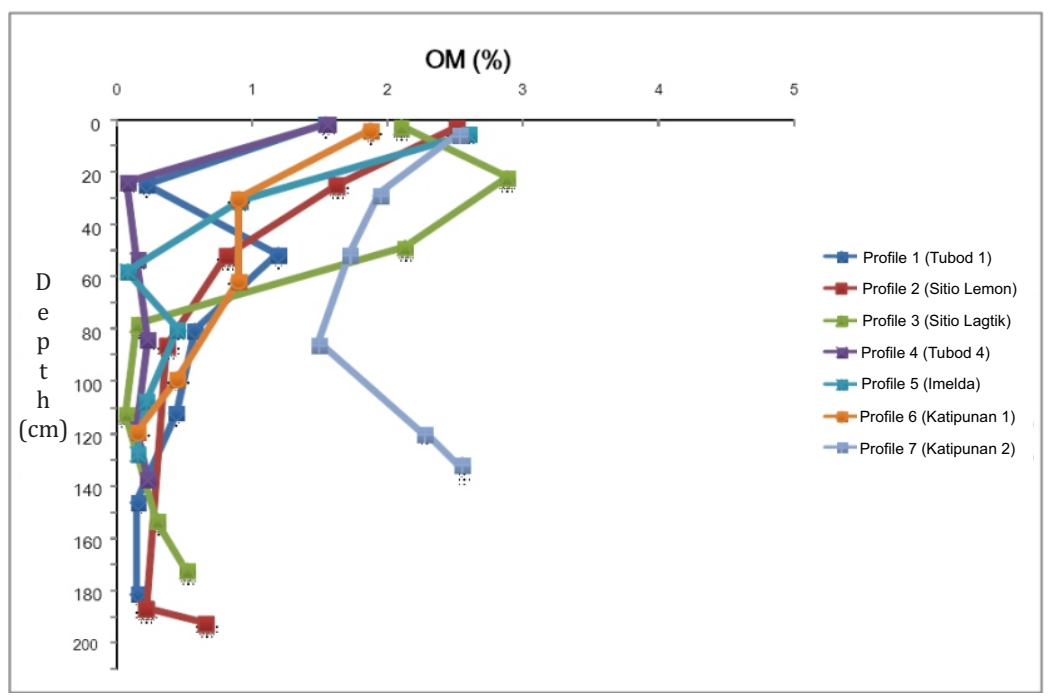

Figure 15. Depth function of OM contents of the strongly weathered soils in Silago, Southern Leyte 
Table 4. Chemical characteristics of the strongly weathered soils in Silago, Southern Leyte

\begin{tabular}{|c|c|c|c|c|c|c|c|c|c|c|c|}
\hline \multirow{2}{*}{$\begin{array}{c}\text { Soil } \\
\text { Profile/ } \\
\text { Horizon }\end{array}$} & \multirow[t]{2}{*}{ Depth (cm) } & \multicolumn{2}{|c|}{$\mathrm{pH}(1: 2.5)$} & \multirow[t]{2}{*}{$\Delta \mathrm{pH}$} & \multirow{2}{*}{$\begin{array}{l}\mathrm{OM} \\
(\%)\end{array}$} & \multirow{2}{*}{$\begin{array}{c}\text { Total N } \\
(\%)\end{array}$} & \multirow{2}{*}{$\begin{array}{c}\text { Available } \\
\mathrm{P} \\
(\mathrm{mg} / \mathrm{kg})\end{array}$} & \multicolumn{4}{|c|}{ Exchangeable Bases $\left(\mathrm{cmol}_{\mathrm{c}} / \mathrm{kg}\right)$} \\
\hline & & $\mathrm{KCl}$ & $\mathrm{H}_{2} \mathrm{O}$ & & & & & K & $\mathrm{Ca}$ & $\mathrm{Mg}$ & $\mathrm{Na}$ \\
\hline \multicolumn{12}{|c|}{ Profile 1 (Tubod) } \\
\hline $\mathrm{Bw}$ & $18-46$ & 4.21 & 5.25 & -1.04 & 1.19 & 0.06 & 0.44 & 0.02 & 0.10 & 0.12 & 0.10 \\
\hline Bt1 & $46-72$ & 4.28 & 5.31 & -1.03 & 0.58 & 0.03 & 0.06 & 0.12 & 0.14 & 0.44 & 0.15 \\
\hline Bt2 & $72-104$ & 4.34 & 5.03 & $-0 . z$ & 0.44 & 0.02 & 0.06 & 0.04 & 0.11 & 0.1 & 0.13 \\
\hline Bt3 & $104-135$ & 4.12 & 5.11 & -0.99 & 0.22 & 0.01 & 0.06 & n.d & n.d & n.d & n.d \\
\hline \multicolumn{12}{|c|}{ Profile 2 (Sitio Lemon) } \\
\hline $\mathrm{Ah}$ & $0-21$ & 3.96 & 4.95 & -0.99 & 2.51 & 0.18 & 0.59 & 0.13 & 0.12 & 0.34 & 0.51 \\
\hline $\mathrm{Bw}$ & $21-44$ & 4.05 & 5.01 & -0.96 & 1.62 & 0.06 & 0.06 & 0.06 & 0.15 & 0.14 & 0.22 \\
\hline Bt1 & $44-75$ & 4.08 & 5.02 & -0.94 & 0.81 & 0.04 & 0.03 & 0.03 & 0.09 & 0.17 & 0.15 \\
\hline Bt2 & $75-113$ & 4.08 & 5.09 & -1.01 & 0.66 & 0.02 & 0.00 & 0.02 & 0.07 & 0.23 & 0.16 \\
\hline $\mathrm{Bt} 3$ & $113-276$ & 4.06 & 5.01 & -0.95 & 0.37 & 0.02 & 0.03 & n.d & n.d & n.d & n.d \\
\hline Bt1 & $39-73$ & 4.13 & 5.03 & -0.90 & 2.10 & 0.04 & 0.07 & 0.04 & 0.16 & 0.22 & 0.11 \\
\hline Bt2 & $73-98$ & 4.14 & 5.02 & -0.88 & 0.52 & 0.03 & 0.03 & 0.02 & 0.15 & 0.15 & 0.05 \\
\hline Bt3 & $98-142$ & 4.07 & 4.91 & -0.84 & 0.30 & 0.02 & 0.03 & n.d & n.d & n.d & n.d \\
\hline Bt4 & $142-180$ & 4.01 & 4.88 & -0.87 & 0.15 & 0.01 & 0.00 & n.d & n.d & n.d & n.d \\
\hline $\mathrm{BC}$ & 180 below & 3.94 & 4.95 & -1.01 & 0.07 & 0.02 & 0.00 & 0.04 & 0.20 & 0.52 & 0.17 \\
\hline \multicolumn{12}{|c|}{ Profile 4 (Tubod 4) } \\
\hline $\mathrm{Ah}$ & $0-18$ & 4.02 & 5.04 & -1.02 & 1.56 & 0.10 & 0.35 & 0.14 & 0.18 & 0.77 & 0.51 \\
\hline Bt1 & $18-45$ & 4.08 & 5.23 & -1.15 & 0.23 & 0.02 & 0.19 & 0.04 & 0.22 & 0.78 & 0.25 \\
\hline Bt2 & $45-77$ & 4.00 & 5.01 & -1.01 & 0.23 & 0.02 & 0.07 & n.d & n.d & n.d & n.d \\
\hline $\mathrm{Bt} 3$ & $77-106$ & 3.96 & 5.00 & -1.04 & 0.15 & 0.02 & 0.03 & 0.04 & 0.19 & 0.30 & 0.10 \\
\hline Bt4 & $106-145$ & 3.94 & 4.97 & -1.03 & 0.15 & 0.01 & 0.03 & n.d & n.d & n.d & n.d \\
\hline $\mathrm{C}$ & 145 below & 3.86 & 4.98 & -1.12 & 0.08 & 0.02 & 0.00 & n.d & n.d & n.d & n.d \\
\hline
\end{tabular}


Table 4 continuation

\begin{tabular}{|c|c|c|c|c|c|c|c|c|c|c|c|}
\hline \multirow{2}{*}{$\begin{array}{c}\text { Soil } \\
\text { Profile/ } \\
\text { Horizon }\end{array}$} & \multirow[t]{2}{*}{ Depth $(\mathrm{cm})$} & \multicolumn{2}{|c|}{$\mathrm{pH}(1: 2.5)$} & \multirow[t]{2}{*}{$\Delta \mathrm{pH}$} & \multirow{2}{*}{$\begin{array}{l}\mathrm{OM} \\
(\%)\end{array}$} & \multirow{2}{*}{$\begin{array}{c}\text { Total N } \\
(\%) \\
\end{array}$} & \multirow{2}{*}{$\begin{array}{c}\text { Available } \\
\mathrm{P} \\
(\mathrm{mg} / \mathrm{kg}) \\
\end{array}$} & \multicolumn{4}{|c|}{ Exchangeable Bases $\left(\mathrm{cmol}_{\mathrm{c}} / \mathrm{kg}\right)$} \\
\hline & & $\mathrm{KCl}$ & $\mathrm{H}_{2} \mathrm{O}$ & & & & & $\mathrm{K}$ & $\mathrm{Ca}$ & $\mathrm{Mg}$ & $\mathrm{Na}$ \\
\hline \multicolumn{12}{|c|}{ Profile 5 (Imelda 1) } \\
\hline $\mathrm{Ah}$ & $0-26$ & 3.86 & 4.64 & -0.78 & 2.59 & 0.14 & 0.51 & 0.11 & 0.17 & 0.21 & 0.11 \\
\hline $\mathrm{Bw}$ & $26-51$ & 3.90 & 4.75 & -0.85 & 0.91 & 0.06 & 0.19 & 0.06 & 0.15 & 0.21 & 0.08 \\
\hline Bt1 & $51-80$ & 3.92 & 4.72 & -0.80 & 0.45 & 0.04 & 0.16 & 0.03 & 0.16 & 0.21 & 0.09 \\
\hline $\mathrm{Bt} 2$ & $80-95$ & 3.91 & 4.78 & -0.87 & 0.22 & 0.03 & 0.12 & n.d & n.d & n.d & n.d \\
\hline $\mathrm{Bt} 3$ & $95-135$ & 3.85 & 4.74 & -0.89 & 0.15 & 0.04 & 0.03 & n.d & n.d & n.d & n.d \\
\hline $\mathrm{BC}$ & 135 below & 3.78 & 4.69 & -0.91 & 0.08 & 0.02 & 0.00 & 0.04 & 0.19 & 0.41 & 0.12 \\
\hline \multicolumn{12}{|c|}{ Profile 6 (Katipunan 1) } \\
\hline Ap & $0-23$ & 5.43 & 6.49 & -1.06 & 1.87 & 0.22 & 0.47 & 0.35 & 0.11 & 9.28 & 0.46 \\
\hline Bt1 & $23-52$ & 6.04 & 6.75 & -0.71 & 0.90 & 0.06 & 0.00 & 0.37 & 0.19 & 4.07 & 0.13 \\
\hline $\mathrm{Bt} 2$ & $52-86$ & 5.96 & 6.60 & -0.64 & 0.90 & 0.04 & 0.00 & 0.30 & 0.19 & 4.16 & 0.15 \\
\hline $\mathrm{BC} 1$ & $86-127$ & 5.44 & 6.17 & -0.73 & 0.45 & 0.03 & 0.03 & 0.18 & 0.25 & 3.72 & 0.14 \\
\hline $\mathrm{BC} 2$ & 127 below & 4.63 & 5.61 & -0.98 & 0.15 & 0.02 & 0.00 & n.d & n.d & n.d & n.d \\
\hline \multicolumn{12}{|c|}{ Profile 7 (Katipunan 2) } \\
\hline Ah1 & $0-25$ & 3.98 & 4.89 & -0.91 & 2.55 & 0.28 & 0.80 & 0.25 & 0.14 & 3.78 & 1.70 \\
\hline Ah2 & $25-46$ & 3.98 & 4.93 & -0.95 & 2.53 & 0.25 & 0.67 & 0.17 & 0.16 & 3.41 & 1.52 \\
\hline $\mathrm{Bw}$ & $46-72$ & 3.95 & 5.01 & -1.06 & 2.27 & 0.24 & 0.42 & 0.16 & 0.15 & 3.70 & 1.66 \\
\hline Bt1 & $72-113$ & 3.83 & 4.86 & -1.03 & 1.94 & 0.23 & 0.35 & 0.11 & 0.11 & 2.36 & 1.14 \\
\hline $\mathrm{Bt} 2$ & $113-143$ & 3.79 & 4.88 & -1.09 & 1.72 & 0.20 & 0.16 & 0.12 & 0.15 & 2.31 & 1.06 \\
\hline $\mathrm{Bt} 3$ & 143 below & 3.86 & 4.88 & -1.02 & 1.49 & 0.16 & 0.03 & n.d & n.d & n.d & n.d \\
\hline
\end{tabular}


Table 4 continuation

\begin{tabular}{|c|c|c|c|c|c|c|c|c|}
\hline $\begin{array}{c}\text { Soil Profile/ } \\
\text { Horizon }\end{array}$ & Depth $(\mathrm{cm})$ & \multicolumn{2}{|c|}{$\begin{array}{c}\text { Exchangeable } \\
\left(\mathrm{cmol}_{\mathrm{c}} / \mathrm{kg}\right)\end{array}$} & $\begin{array}{c}\text { Exchangeable } \\
\text { Acidity } \\
\left(\mathrm{cmol}_{\mathrm{c}} / \mathrm{kg}\right)\end{array}$ & \multicolumn{2}{|c|}{$\mathrm{CEC}\left(\mathrm{cmol}_{\mathrm{c}} / \mathrm{kg}\right)$} & $\begin{array}{l}\text { CEC Clay } \\
\left(\mathrm{cmol}_{\mathrm{c}} / \mathrm{kg}\right)\end{array}$ & $\begin{array}{c}\text { Base Saturation } \\
(\%)\end{array}$ \\
\hline \multicolumn{9}{|c|}{ Profile 1 (Tubod) } \\
\hline $\mathrm{Bw}$ & $18-46$ & 0.90 & 0.7 & 1.60 & 34.48 & 1.94 & 57.66 & 0.99 \\
\hline Bt1 & $46-72$ & 0.57 & 0.20 & 0.76 & 29.83 & 1.61 & 49.70 & 2.85 \\
\hline $\mathrm{Bt} 2$ & $72-104$ & 0.39 & 0.36 & 0.75 & 50.05 & 1.13 & 84.90 & 0.76 \\
\hline $\mathrm{BC}$ & $172-206$ & 2.38 & 0.75 & 3.13 & 17.68 & 3.81 & 30.41 & 3.85 \\
\hline \multicolumn{9}{|c|}{ Profile 2 (Sitio Lemon) } \\
\hline $\mathrm{Ah}$ & $0-21$ & 1.52 & 0.49 & 2.01 & 25.36 & 3.11 & 65.87 & 4.34 \\
\hline $\mathrm{Bw}$ & $21-44$ & 1.23 & 0.49 & 1.72 & 25.57 & 2.29 & 51.09 & 2.23 \\
\hline Bt1 & $44-75$ & 1.54 & 0.18 & 1.72 & 30.67 & 2.16 & 60.00 & 1.43 \\
\hline $\mathrm{Bt} 2$ & $75-113$ & 1.28 & 0.38 & 1.67 & 36.73 & 2.15 & 71.39 & 1.31 \\
\hline $\mathrm{Bt} 3$ & $113-276$ & 1.33 & 0.43 & 1.77 & 32.95 & n.d & 63.37 & n.d \\
\hline \multicolumn{9}{|c|}{ Profile 3 (Sitio Lagtik) } \\
\hline Bt1 & $39-73$ & 1.01 & 0.34 & 1.35 & 18.94 & 1.88 & 31.62 & 2.80 \\
\hline $\mathrm{Bt} 2$ & $73-98$ & 0.96 & 0.24 & 1.19 & 14.80 & 1.56 & 24.66 & 2.50 \\
\hline $\mathrm{Bt} 3$ & $98-142$ & 1.29 & 0.17 & 1.46 & 22.15 & n.d & 36.84 & n.d \\
\hline Bt4 & $142-180$ & 1.36 & 0.22 & 1.58 & 26.62 & n.d & 44.39 & n.d \\
\hline $\mathrm{BC}$ & 180 below & 1.60 & 0.33 & 1.92 & 16.70 & 2.85 & 27.81 & 5.57 \\
\hline \multicolumn{9}{|c|}{ Profile 4 (Tubod 4) } \\
\hline $\mathrm{Ah}$ & $0-18$ & 1.02 & 1.09 & 2.12 & 23.57 & 3.72 & 48.10 & 6.79 \\
\hline Bt1 & $18-45$ & 0.92 & 0.69 & 1.61 & 28.71 & 2.90 & 48.87 & 4.49 \\
\hline $\mathrm{Bt} 2$ & $45-77$ & 1.88 & 0.48 & 2.36 & 26.95 & n.d & 45.68 & n.d \\
\hline $\mathrm{Bt} 3$ & $77-106$ & 1.89 & 0.26 & 2.16 & 23.33 & 2.79 & 39.46 & 2.70 \\
\hline $\mathrm{Bt} 4$ & $106-145$ & 1.03 & 0.90 & 1.94 & 26.77 & n.d & 44.62 & n.d \\
\hline $\mathrm{C}$ & 145 below & 2.20 & 0.64 & 2.85 & 15.42 & n.d & 25.70 & n.d \\
\hline
\end{tabular}


Table 4 continuation

\begin{tabular}{|c|c|c|c|c|c|c|c|c|}
\hline \multirow[t]{2}{*}{$\begin{array}{c}\text { Soil Profile/ } \\
\text { Horizon }\end{array}$} & \multirow[t]{2}{*}{ Depth $(\mathrm{cm})$} & \multicolumn{2}{|c|}{$\begin{array}{c}\text { Exchangeable } \\
\left(\mathrm{cmol}_{\mathrm{c}} / \mathrm{kg}\right)\end{array}$} & \multirow{2}{*}{$\begin{array}{c}\text { Exchangeable } \\
\text { Acidity } \\
\left(\mathrm{cmol}_{\mathrm{c}} / \mathrm{kg}\right)\end{array}$} & \multicolumn{2}{|c|}{$\mathrm{CEC}\left(\mathrm{cmol}_{\mathrm{c}} / \mathrm{kg}\right)$} & \multirow[t]{2}{*}{ CEC Clay } & \multirow{2}{*}{$\begin{array}{c}\text { Base } \\
\text { Saturation } \\
(\%)\end{array}$} \\
\hline & & $\mathrm{Al}^{3+}$ & $\mathrm{H}^{+}$ & & Pot & Eff & & \\
\hline \multicolumn{9}{|l|}{ Profile 5 (Imelda) } \\
\hline $\mathrm{Ah}$ & $0-26$ & 1.86 & 1.00 & 2.86 & 20.59 & 3.46 & 51.63 & 2.91 \\
\hline Bw & $26-51$ & 2.14 & 0.48 & 2.62 & 35.07 & 3.12 & 90.27 & 1.43 \\
\hline Bt1 & $51-80$ & 2.17 & 0.42 & 2.59 & 17.94 & 3.08 & 32.62 & 2.73 \\
\hline $\mathrm{Bt} 2$ & $80-95$ & 2.04 & 1.07 & 3.11 & 31.18 & n.d & 55.81 & n.d \\
\hline Bt3 & $95-135$ & 2.57 & 0.45 & 3.02 & 20.74 & n.d & 37.10 & n.d \\
\hline $\mathrm{BC}$ & 135 below & 2.69 & 0.62 & 3.31 & 20.25 & 4.07 & 36.08 & 3.75 \\
\hline \multicolumn{9}{|c|}{ Profile 6 (Katipunan 1 ) } \\
\hline Ap & $0-23$ & 0.06 & 0.22 & 0.27 & 14.65 & 10.47 & 39.55 & 69.62 \\
\hline Bt1 & $23-52$ & 0.06 & 0.44 & 0.49 & 32.69 & 5.25 & 85.80 & 14.56 \\
\hline Bt2 & $52-86$ & 0.11 & 0.30 & 0.41 & 23.58 & 5.21 & 40.90 & 20.36 \\
\hline $\mathrm{BC} 1$ & $86-127$ & 0.06 & 0.36 & 0.41 & 31.23 & 4.70 & 54.05 & 13.74 \\
\hline $\mathrm{BC} 2$ & 127 below & 0.11 & 0.33 & 0.44 & 18.66 & n.d & 32.11 & n.d \\
\hline \multicolumn{9}{|c|}{ Profile 7 (Katipunan 2) } \\
\hline Ah1 & $0-25$ & 1.40 & 0.00 & 1.41 & 11.31 & 7.28 & 23.40 & 51.90 \\
\hline Ah2 & $25-46$ & 1.36 & 0.86 & 2.22 & 14.90 & 7.48 & 30.41 & 35.30 \\
\hline $\mathrm{Bw}$ & $46-72$ & 1.37 & 0.52 & 1.89 & 12.03 & 7.56 & 20.38 & 47.13 \\
\hline Bt1 & $72-113$ & 2.56 & 0.59 & 3.16 & 13.68 & 6.88 & 23.01 & 27.19 \\
\hline $\mathrm{Bt} 2$ & $113-143$ & 2.98 & 1.33 & 4.31 & 17.94 & 7.95 & 29.90 & 20.29 \\
\hline $\mathrm{Bt} 3$ & 143 below & 1.76 & 0.52 & 2.28 & 21.87 & n.d & 36.33 & n.d \\
\hline
\end{tabular}


Base saturation refers to the proportion of the cation exchange sites in the soil that are occupied by the various cations such as $\mathrm{K}, \mathrm{Ca}, \mathrm{Mg}$, and $\mathrm{Na}$. Table 4 shows that profiles 6 and 7 have the highest values due to their higher exchangeable bases content compared to the other soil profiles. Base saturation is positively related to soil $\mathrm{pH}$ because a high base saturation value indicates that the exchange sites on a soil particle are dominated by non-acidic ions.

Exchangeable bases are the exchangeable basic cations that are adsorbed on the exchange sites of soil colloids. These include calcium (Ca), magnesium $(\mathrm{Mg})$, potassium $(\mathrm{K})$, and sodium $(\mathrm{Na})$. Results show that generally the four (4) exchangeable bases are low in all soils and tend to decrease with depth which may be attributed to low inherent content from the parent material as well as to the low $\mathrm{pH}$ values of the soils (Table 4).

The capacity of the soil to adsorb or to hold cations and to exchange species of ions is termed as cation exchange capacity or CEC. The conventional CEC method (by $1 \mathrm{~N} \mathrm{NH}_{4} \mathrm{OAc}$ at $\mathrm{pH}$ 7.0) measures the potential CEC of the soil ( $\mathrm{CEC}_{\mathrm{pot}}$ ) while the "alternative method," which involves the summation of basic cations (extracted by $1 \mathrm{~N} \mathrm{NH}_{4} \mathrm{OAc}$ at $\mathrm{pH}$ 7.0) plus the $1 \mathrm{M} \mathrm{KCl}$ exchangeable acidity, measures the effective $\mathrm{CEC}$ of the soil $\left(\right.$ CEC $\left._{\text {eff }}\right)$ (ISRIC, 1995). The effective CEC is probably a more meaningful value as far as plant growth, fertilizer additions, and liming are concerned than the potential CEC determined with the buffered solutions at high $\mathrm{pH}$ values (Tisdale and Nelson, 1975). Results show that $\mathrm{CEC}_{\mathrm{pot}}$ and $\mathrm{CEC}_{\text {eff }}$ are both higher in the upper two (2) horizons in all profiles compared to the lower horizons, and the two also decrease with depth (Figures 16 and Table 4). Higher CEC in the upper horizons could be attributed to the organic matter, which is higher in the upper horizons. Results suggest that the surface soil contains high amounts of variable charge than the subsoil. The low CEC in the subsoil or deeper part of the soil profile may also be attributed to the clay mineral types and to the low organic matter content.

It can be observed also that $\mathrm{CEC}_{\text {pot }}$ values are higher than $\mathrm{CEC}_{\text {eff }}$ values. The high potential CEC values indicate that considerable amount of negative charge was produced with the raising of $\mathrm{pH}$ to 7.0 during soil analysis (Scheffer and Schachtschabel, 1992). Tisdale and Nelson (1975) also pointed out that the use of ammonium acetate method will result in a high CEC value if the soil is acid simply because of the adsorption of $\mathrm{NH}_{4}^{+}$ ions in the so-called $\mathrm{pH}$-dependent exchange sites.

Exchangeable acidity is the amount of $\mathrm{H}^{+}$and $\mathrm{Al}^{3+}$ in the exchange complex of the soil extracted by $1 \mathrm{M} \mathrm{KCl}$. Results show that exchangeable 
Characteristics of Strongly Weathered Soils in Silago

$\mathrm{Al}^{3+}$ is the major component of exchangeable acidity in all soils (Table 4). The increase in $\mathrm{Al}^{3+}$ with depth corresponds to the decrease of $\mathrm{pH}-\mathrm{H}_{2} \mathrm{O}$ and $\mathrm{pH} \mathrm{KCl}$. The result indicates that under acid condition, $\mathrm{Al}^{3+}$ is the major cation in the soil (Kamprath, 1980).

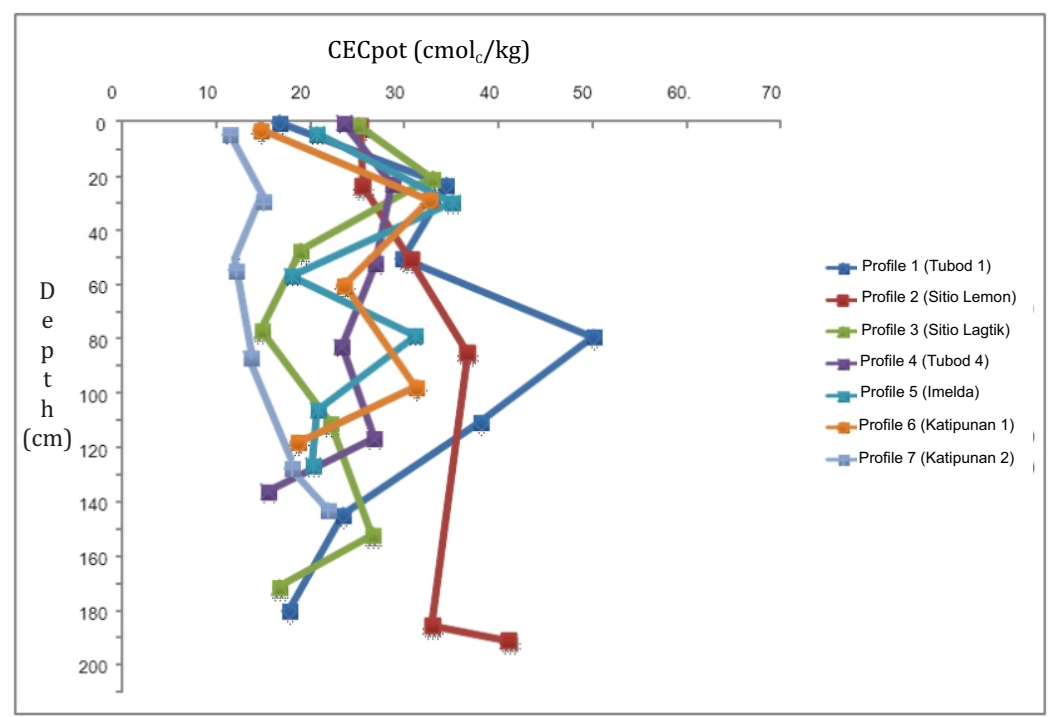

Figure 16. Depth function of potential CEC of the strongly weathered soils in Silago, Southern Leyte

\section{Clay Mineralogy and Classification}

Due to the unavailability of an X-ray diffraction (XRD) apparatus for identifying low- $\left(<24 \mathrm{cmol}_{c} / \mathrm{kg}\right.$ clay $)$ and high-activity clay ( $\geq 24 \mathrm{cmol}_{\mathrm{c}} / \mathrm{kg}$ clay, WRB 2014) the following formula was used (compare with ISRIC, 1995).

$$
\mathrm{CEC}_{\text {clay }}=\frac{\mathrm{CEC}_{\text {pot }}-\mathrm{CEC}_{\text {org }} \times 3.5}{\text { \%clay }} \times 100
$$

Where:

$\mathrm{CEC}_{\text {pot }}$ is the CEC determined by ammonium acetate

$\mathrm{pH} 7.0\left(\mathrm{cmol}_{\mathrm{c}} / \mathrm{kg}\right)$
$\%$ clay is the amount of clay of the sample

method at

$\mathrm{C}_{\text {org }}=$ Organic matter / 1.724 
Results show that most of the soils have high activity clay with either montmorillonite or mixed mineralogy. Only the Bt2 of profile 3 and most horizons of profile 7 have low-activity clay but do not fit the requirements of a kandic horizon ( $<16 \mathrm{cmol}_{c} / \mathrm{kg}$ clay; (USDA, 1996). Earlier pedological studies in Leyte have shown that the strongly weathered volcanic soils are dominated by kaolinite and halloysite clay minerals (Asio, 1996; Navarrete et al., 2009). Thus, it appears that the pedotransfer equation is not applicable to the soils studied.

According to Soil Taxonomy (USDA, 1999), soil profiles 1 to 6 are classified as Typic Hapludults. The reason is that they belong to the order Ultisol that have an argillic horizon and percent base saturation of less than 35. They also have an udic moisture regime (Udults) and possess characteristics that do not qualify under the criteria of other groups of Udults (Hapludults). On the other hand, soil profile 7 is classified as Typic Hapludalf. This soil belongs to the order Alfisols. Like Ultisols, it possesses an argillic horizon but it has more than 35 percent base saturation which means it is more fertile than the Ultisols. Soil profile 7 also appears younger than the soils in the upper physiographic position probably because of periodic deposition of soil materials and elements.

In the WRB (2014), soil profiles 1 to 6 are classified as Alisol which indicate soils having an argic horizon with a cation exchange capacity (by 1 $\mathrm{M} \mathrm{NH}_{4} \mathrm{OAc}$ ) equal to or more than $24 \mathrm{cmol}_{c} \mathrm{~kg}^{-1}$ clay throughout the profile. Soil profile 7 can be classified as a Luvisol.

\section{CONCLUSION}

Based on the results of the study, it may be concluded that:

1. The soils studied have colors ranging from yellowish brown to yellowish red, have subangular blocky structure, clay in texture, deep $(>3 \mathrm{~m})$, friable when moist but very plastic and very sticky when wet, and have moderate to high porosity values. For the chemical properties, the soils have low $\mathrm{pH}-\mathrm{H}_{2} \mathrm{O}$ values ranging from 4.52 to 6.75 with profile 6 as the highest, potential CEC of 11.31 to $38.13 \mathrm{cmol}_{\mathrm{c}} / \mathrm{kg}$, base saturation of 0.76 to $69.62 \%$, organic matter content of 0.07 to $2.59 \%$,total N of 0.01 to $0.28 \%$, and available P of less than $5 \mathrm{mg} / \mathrm{kg}$.

2. The soils have closely related properties probably due to by their similar parent material, original vegetation (rainforest) and climate. The differences in some soil properties appear to be largely the effect of topography. 
3. Most of the soils are classified as Typic Hapludults in the USDA Soil Taxonomy or Haplic Alisols in the WRB, which reflect their strongly weathered characteristics while the soil in the lowest part of the landscape (toeslope) is classified as Typic Hapludalf or Haplic Luvisol which indicates that it is slightly younger than the other soils.

\section{ACKNOWLEGEMENT}

This paper was based on the MSc thesis of the first author which was funded by a thesis grant from the ASTHRDP of the Department of Science and Technology (DOST) through the National Science Consortium. We are very grateful to Prof. Dr. Reinhold Jahn, University of Halle-Wittenberg, Germany, for his comments and suggestions which greatly improved the paper.

\section{REFERENCES}

ASIO, V.B., R. ARMECIN, and A.T. BAUTISTA 1992.Relationship between exchangeable aluminum and $\mathrm{pH}$ in some acidic Philippine soils. Phil. J. Sci. 121:383-390

ASIO, V.B. 1996. Characteristics, weathering formation, and degradation of soils from volcanic rocks in Leyte, Philippines.Hohenheimer Bodenkundliche Hefte 33. Stuttgart, Germany. 209 pp.

ASIO, V.B. AND M.J.M. BANDE 2005. Innovative community-led sustainable forest resource conservation and management in Baybay, Leyte, Philippines. In: Innovative Communities: People-Centered Approaches to Environmental Management in the Asia-Pacific Region (Velasquez, J., Yashiro, M., I. Ono, eds.). United Nations University Press, Tokyo-ParisNew York, pp: 204-224

BARRERA, A., I. ARISTORENAS, and J. TINGZON 1954. Soil survey of Leyte Province, Philippines. Bureau of Print, Manila

BLAKE, G.R. and K.H. HARTGE 1986. Methods of soil analysis, Part 1. American Society of Agronomy-Soil Science Society of America, 677 South Segoe Road, Madison, WI 53711, USA 
BLUM, W.E.H. 1983. Zur Bodennutzung der feuchten Tropen-dasgestellt am Beispiel des Amazonasgebietes Brasilians. Giessener Beitrage zur Entwicklungsforschung, Giessen, Reihe I, Band 9: 7-25

BRADY, N.C. and R.R. WEIL 1999.Nature and properties of soils (13 ${ }^{\text {th }}$ ed.). Prentince-Hall, Inc. A Simon Shufer Comp., New Jersey, USA

BRAY, R.H. and L.T. KURTZ 1945. Determination of total, organic, and available forms of phosphorus in soils. Soil Sci. 59: 39-45

BUOL, S.W., F.D. HOLE, R.J. MCCRACKEN, and R.J. SOUTHARD 1997. Soil genesis and classification ( $4^{\text {th }}$ ed.). Iowa State University Press, Ames, IA

BUTLER, B.E. 1982.A new system of soil studies. Journal Soil Science. 33: 581-595

CORONAS, J. 1920.The climate and weather of the Philippines. Bureau of Print, Manila, Philippines.189 pp.

ESWARAN, H., J. KIMBLE, T. COOK, and F.H. BEINROTH 1992. Soil diversity in the tropics: Implications for agricultural development. In: Myths and science of soils of the tropics. R. Lal and P.A. Sanchez (eds). SSSA Special Publication No.29: 1-16

FAO 1988. Soil maps of the world. Revised legend. Rome.119 pp.

FAO 2006. Guidelines of Soil Description $\left(4^{\text {th }}\right.$ ed). FAO, Rome.97 pp.

HART, J., HEARN, G., and CHANT, C. 2002. Engineering on the precipice: Mountain road rehabilitation in the Philippines. Quart. Jour. Eng. Geol. 35: 223-231

INTERNATIONAL SOIL REFERENCE and INFORMATION CENTER (ISRIC) 1995. Procedures for soil analysis (L.P. Van Reuwijk, ed.). Wageningen, The Netherlands. 106 pp.

JAHN, R.H., H.P. BLUME, and V.B. ASIO 2002. Students' guide for soils description, site classification, and site evaluation. Polish German Soils Societies, Halle/ Saale. 200 pp. 
Characteristics of Strongly Weathered Soils in Silago

JENNY, H. 1941. Factors of soil formation: A system of quantitative pedology. Mc-Graw Hill, New York

JICA1990. Report on the mineral exploration of mineral deposits and tectonics of two contrasting geologic environment in the Republic of the Philippines. Japan International Corporation Agency, Metal Mining Agency of Japan.121 pp.

KAMPRATH, E. 1980. Soil acidity in well-drained soils of the tropics as a constraint to food production. In: Priorities for alleviating soil-related constraints to food production in the tropics. IRRI, Los Banos, Laguna, Philippines.171-187 pp.

LANDON, J.R. 1991. Booker tropical soil manual. Longman Scientific and Technical, England.474 pp.

MEKARU, T. and G. UEHARA 1972. Anion adsorption in ferruginous tropical soils.Soil Sci. Soc.Amer. Proc. 36: 296-300

NAVARRETE, I.A., V.B. ASIO, E. BALBARINO, and A. TULIN 2000. The physicchemical properties of rhizosphere soil of vetiver grass grown in a degraded upland. Grassland Society of the Philippines Journal. 4: 29-34

NAVARRETE, I.A., K. TSUTSUKI, V.B. ASIO, and R. KONDO 2009. Characteristics and formation of rainforest soils derived from quaternary basaltic rocks in Leyte, Philippines. Envi.Geology. 58: $1257-1268$

NAVARRETE I.A., K. TSUTSUKI, V.B. ASIO AND R. KONDO 2010. Characteristics and formation of rainforest soils derived from late Quaternary basaltic rocks in Leyte, Philippines. Environmental Geology 58: 1257-1268.

NELSON, D.W. and L.E SOMMERS 1982. Methods of soil analysis, Part II. American Society of Agronomy-Soil Science Society of America, 677 South Segoe Road, Madison, WI 53711, USA 
Piamonte et al.

NSSC (National Soil Survey Center) 1995. Soil survey laboratory information manual. Soil Survey Information Report No. 45, Version 1.0, May 1995. Soil Survey Lab., Lincoln, Nebraska, NRCS-USDA. 305 pp.

SANCHEZ, P.A. 1976. Properties and management of soils in the tropics.Wiley and Sons, New York, NY.168 pp.

SANCHEZ, P.A. and T.J. LOGAN 1992. Myths and science about the chemistry and fertility of soils in the tropics. In: Myths and science of soils of the tropics. SSSA Special Publication No. 29, Madison, Wisconsin.35-46 pp.

SCHEFFER, F. and P. SCHACHTSCHABEL 1992. Lehrbuch der Bodenkunde. Durchgesehene Auflage. FerdinandEnke Verlag, Stuttgart, Germany. $491 \mathrm{pp}$.

SCHLICHTING, E., H.P. BLUME, and K. STAHR 1995. Bodenkundliches Praktikum $\left(2^{\text {nd }}\right.$ ed. $)$. Blackwell: Berlin

SIMON, J.D., N.M. NATIVIDAD, R.M. AMABA, and T.P. DEMEN 1975. Soil survey of Samar Provinces, Philippines. Bureau of Prints, Manila

SOIL SURVEY STAFF 1996. Soil survey laboratory methods manual. Soil Survey Investigations Rep. 42. USDA-NRCS. U.S. Gov. Print. Office, Washington, DC.994 pp.

STAHR, K. 1994. Soil minerals in space and time. Trans. $15^{\text {th }}$ World Congr. Soil Sci., Mexico. 1:111-121

THOMAS, G.W. 1982. Exchangeable cations. In: A.L. PAGE, Editor: Methods of soil analysis. Part 2.Chemical and microbiological properties. ( $2^{\text {nd }}$ ed.). Agron. Soc. Amer., Inc. and Soil Sci. Soc. Amer. Inc., Madison, Wisconsin.159-165 pp.

TISDALE, S.L. and W.L. NELSON 1975.Soil fertility and fertilizers ( $3^{\text {rd }}$ ed. $)$. Macmillan Publishing Co., Inc. New York. 107-109 pp.

UNITED STATES DEPARTMENT OF AGRICULTURE (USDA) SOIL SURVEY STAFF 2014. Keys to soil taxonomy $\left(12^{\text {th }}\right.$ ed.). Natural Resources Conservation Service. $360 \mathrm{pp}$. 
Characteristics of Strongly Weathered Soils in Silago

YOUNG, A. 1976. Tropical soils and soil survey. Cambridge Univ. Press, Cambridge. 468 pp.

UNITED STATES GEOLOGICAL SURVEY (USGS) NATIONAL PARK SERVICE 2000. Department of the Interior

VAN RAIJ, B. and M. PEECH 1972. Electrochemical properties of some Oxisols and Alfisols of the tropics. Soil Sci. Soc. Am. Proc. 36: 587-593

WRB 2014. World reference base for soil resources. World Soil Resources Report 106, ISRIC- FAO, Rome, Italy. 181pp. 